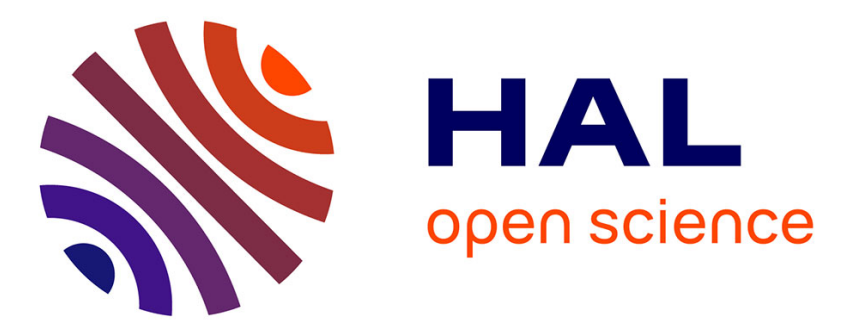

\title{
18th ICPR paper: TOTAL COST OF OWNERSHIP ANALYSIS FOR MODULAR FINAL ASSEMBLY SYSTEMS
}

\author{
Juhani Heilala, Kaj Helin, Jari Montonen
}

\section{- To cite this version:}

Juhani Heilala, Kaj Helin, Jari Montonen. 18th ICPR paper: TOTAL COST OF OWNERSHIP ANALYSIS FOR MODULAR FINAL ASSEMBLY SYSTEMS. International Journal of Production Research, 2006, 44 (18-19), pp.3967-3988. 10.1080/00207540600806448 . hal-00512925

\section{HAL Id: hal-00512925 \\ https://hal.science/hal-00512925}

Submitted on 1 Sep 2010

HAL is a multi-disciplinary open access archive for the deposit and dissemination of scientific research documents, whether they are published or not. The documents may come from teaching and research institutions in France or abroad, or from public or private research centers.
L'archive ouverte pluridisciplinaire HAL, est destinée au dépôt et à la diffusion de documents scientifiques de niveau recherche, publiés ou non, émanant des établissements d'enseignement et de recherche français ou étrangers, des laboratoires publics ou privés. 


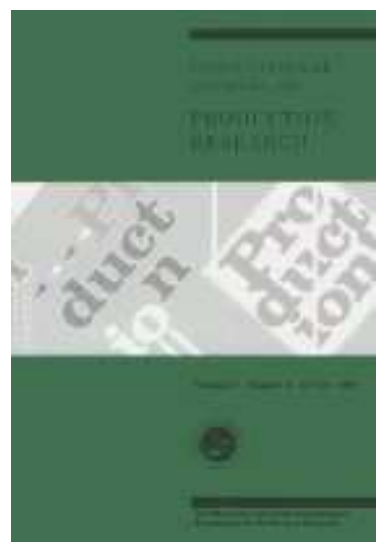

\section{8th ICPR paper: TOTAL COST OF OWNERSHIP ANALYSIS FOR MODULAR FINAL ASSEMBLY SYSTEMS}

\begin{tabular}{|r|l|}
\hline Journal: & International Journal of Production Research \\
\hline Manuscript ID: & TPRS-2005-IJPR-0573.R1 \\
\hline Manuscript Type: & Original Manuscript \\
\hline $\begin{array}{r}\text { Date Submitted by the } \\
\text { Author: }\end{array}$ & 28 -Apr-2006 \\
\hline $\begin{array}{r}\text { Complete List of Authors: } \\
\text { Keilala, Juhani; VTT Technical Research Centre of Finland } \\
\text { Helin, Kaj; VTT Technical Research Centre of Finland } \\
\text { Montonen, Jari; VTT Technical Research Centre of Finland }\end{array}$ & ASSEMBLY SYSTEMS, DESIGN, COST ANALYSIS \\
\hline Keywords (user): & efficiency analysis \\
\hline &
\end{tabular}

\section{ScholarONE" \\ Manuscript Central}


Abstract

The objective of modern assembly processes is to produce high-quality and low-cost products. Understanding manufacturing costs in the system design phase is the first step to increasing profits. Throughput, utilisation and cycle time continue to be emphasised as key performance indicators (KPI) for the planning of new assembly systems, but the cost issues need to be analysed as well. The authors are developing a novel analysis methodology that integrates component-based simulation, Overall Equipment Efficiency (OEE) with Cost of Ownership (COO) and other analysis methods to improve the design of flexible, modular re-configurable assembly systems. The development of the Total Cost of Ownership (TCO) analysis tool is based on selected industrial standards and the authors' own experience of assembly system design and simulation. The TCO method is useful in system-supplier and end-user communication and helps in trade-off analysis of system concepts. A fictitious case study illustrates the use of the TCO method.

Keywords: Assembly system design, cost and efficiency analysis 


\title{
TOTAL COST OF OWNERSHIP ANALYSIS FOR MODULAR FINAL ASSEMBLY SYSTEMS
}

\begin{abstract}
The objective of modern assembly processes is to produce high-quality and low-cost products. Understanding manufacturing costs in the system design phase is the first step to increasing profits. Throughput, utilisation and cycle time continue to be emphasised as key performance indicators (KPI) for the planning of new assembly systems, but the cost issues need to be analysed as well. The authors are developing a novel analysis methodology that integrates component-based simulation, Overall Equipment Efficiency (OEE) with Cost of Ownership (COO) and other analysis methods to improve the design of flexible, modular re-configurable assembly systems. The development of the Total Cost of Ownership (TCO) analysis tool is based on selected industrial standards and the authors' own experience of assembly system design and simulation. The TCO method is useful in system-supplier and end-user communication and helps in trade-off analysis of system concepts. A fictitious case study illustrates the use of the TCO method.
\end{abstract}

Keywords: Assembly system design, cost and efficiency analysis 


\section{Introduction}

The design of an assembly line or cell is an old problem but also a new one. New innovations in product and manufacturing technology often result in new design problems. On the one hand, technological advances lead to more sophisticated assembly systems; on the other, market competition causes shortened product lifetimes, which force a change or reduction in the service years of the assembly system. The assembly system design, therefore, plays an increasingly important role in manufacturing. The design work should be guided by a systematic approach, with careful evaluation of the design concept from both cost and performance viewpoints. A cost item usually measures the total amount of spending needed to produce a given number of products. This may include product design, development, laboratory testing, and all of the spending required to support production activity, such as direct and indirect labour, equipment, facilities and other overheads. The ratio of total spending to the total number of products is then the product unit cost [Chow 1990].

The ability to effectively identify cost drivers and manage cost reductions is a competitive advantage, and this should be done as early as possible in the assembly system concept evaluation and selection phase. Different cost estimation methods have been devised; a few of them measure intangible costs, such as flexibility, product yield, parts quality, process time variation, and so on. Although not all of these intangibles are easily understood, their costs may be measured by indirect methods. In many cases, a cost estimation method can be derived from performance measures. For example, flexibility would impact on the capital investment plan. Yield and quality are related to 
capacity and material handling costs. Process time variation may cause problems with workstation utilisation or in-process inventories [Chow 1990].

Final assembly systems in the electronics industry do have a modular structure. System reconfiguration is needed in the current market climate, where system changes occur at shorter and shorter intervals. The modular structure, the architecture of the assembly system, has many advantages. It facilitates standardisation in that at least the selected suppliers' modules are compatible and the system is scaleable. The system building blocks can be divided into basic process platforms, exchangeable process modules and, finally, product-related components; naturally, there are buffer modules and modules for arranging the material flow. The design of the modular system is just like selecting the suitable modules from a catalogue and placing them in the right order to get the correct process flow and system layout. Modularity is a cost-efficient solution; it supports stepby-step investment, and later upgrades or modifications to the system are also easier. Standardised building blocks also help in calculating the cost of investment. Most of the modules should be standard with known catalogue prices, thus product-related special customisation is minimised.

Simulation and virtual factory technology is commonly used for manufacturing system design. Simulation studies can show the performance of the planned system and different alternatives can be studied before the investment decision. Simulation software with 3D visualisation capabilities does improve communication with different interest groups. A modular system solution configuration can be greatly enhanced with the proper design and evaluation tools, see Figure 1. 
Component-based simulation software is ideal for the design and configuration of modular reconfigurable systems. A suitable simulation tool, like [Visual Components, 2006], supports modularity at different levels: the workstation or basic process platform and process modules. The building blocks, "visual components", used in the simulation should be parametric in nature, have geometry, behaviour and interface just like real system modules. The use of simulation library components greatly speeds up model building. Library components have high reuse value and the "build once, use multiple times' ideal is a reality. Model building with predefined modules is a process similar to 'drag and drop' or 'copy and paste'. 
The authors believe that simulation, system modelling, COO and OEE are becoming increasingly important in high-tech decision-making processes as shown in the article. Systematic methods do improve the quality of decisions and communication. There is need for fast analysis, which could be carried out during a sales meeting and this is one of the development aims (See Figure 2). The difficulty is to get the right information for simulation analysis. Collaboration between system suppliers with equipment knowledge and end users with product and process knowledge does improve the accuracy of the simulation analysis.

The novelty of the development is in the integration of different analysis methods to improve the design of modular assembly systems. (See Figure 2. and 3)

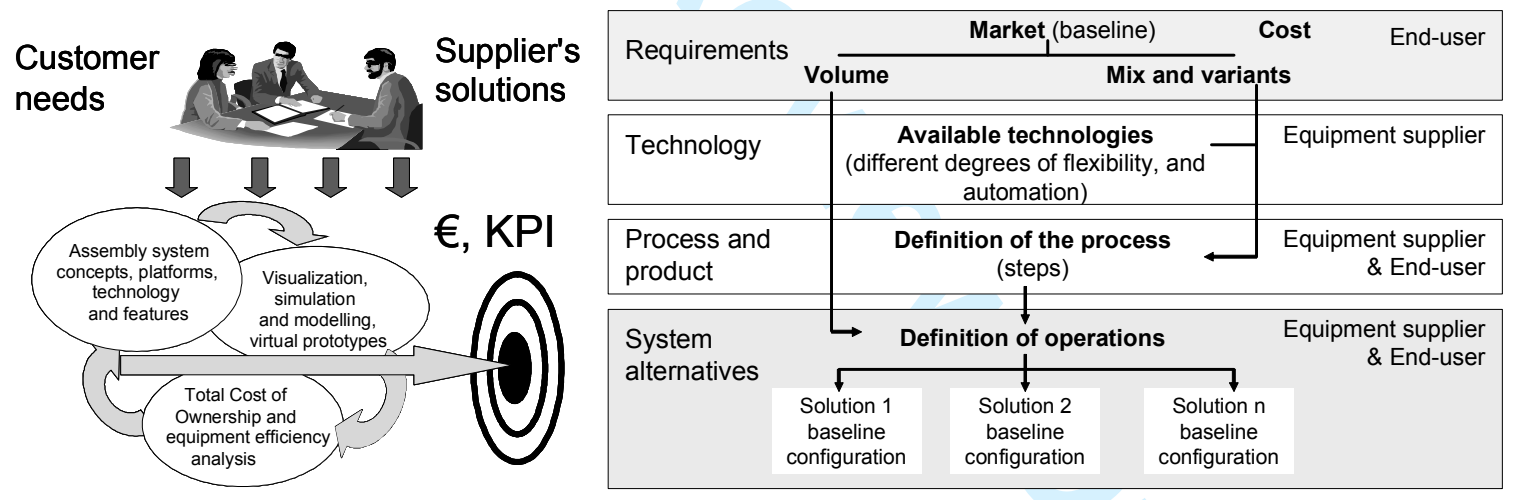

Figure 2: The development aims to improve design quality and communication. 


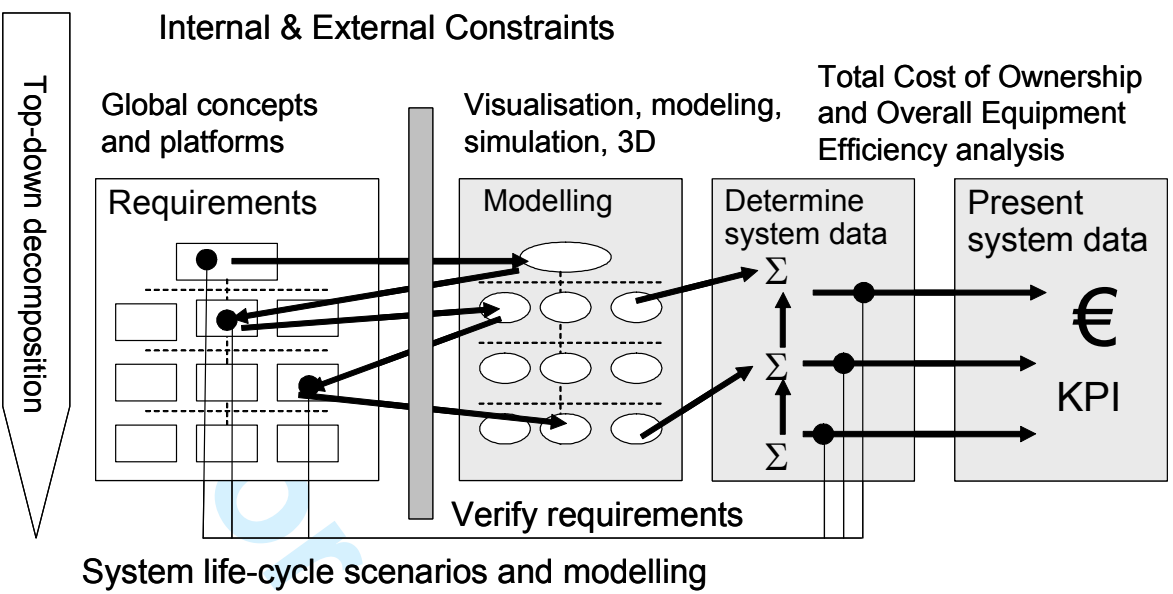

Figure 3: Form requirements to assembly system cost efficiency

The development presented here is part of the Eureka Factory E!-2851 E-Race project, www.e-race.info. The national project consortium in Finland, research institutes, technology providers and end users worked together to create next-generation modular assembly systems and an enhance design methodology. This paper was originally presented in 2005 [Heilala et al. 2005a]. Now later advances [Heilala et al, 2005 b, Heilala et al 2006] are summarised in this paper. The remainder of the paper is organised as follows. Sections 2 and 3 describe the theories behind the methodology and the integration of different analysis methods. In section 4, the methodology is presented through a case study. This is followed by an analysis and comparison of the developed methodology. 


\section{Theory for TCO methodology development}

In this section, cost and efficiency analysis theories are briefly shown. The following chapter describes some commonly used life cycle cost analysis methods and the use of these methods.

\subsection{Life Cycle and Cost of Ownership analysis}

LCC for process industry. Life cycle costs (LCC) are summations of the estimated cost from inception to disposal for both equipment and projects as determined by an analytical study and an estimate of the total costs experienced during the life of equipment or projects (Barringer 1996). The objective of LCC analysis is to choose the most cost effective approach from a series of alternatives so that the least long-term cost of ownership is achieved while considering cost elements which include design, development, production, operation, maintenance, support, and final disposition of a major system over its anticipated useful life span. LCC methodology is commonly used in process industry, often also applied to energy technologies and building projects.

TCO for Information Technology. Total Cost of Ownership (TCO) Modelling is a tool that systematically accounts for all costs related to an IT (Information Technology) investment decision. TCO models were initially developed by Gartner Research in 1987 and are now widely accepted (Wikipedia 2006). Simply stated, TCO includes all costs, direct and indirect, incurred throughout the life cycle of an asset, including acquisition and procurement, operations and maintenance, and end-of-life management. 
Other uses for TCO. Similar TCO concepts are widely used in the automobile industry. In this context, the TCO denotes the cost of owning a vehicle from the purchase, through its maintenance, and finally its sale as a used car. Comparative TCO studies between various car models help consumers choose a car to fit their needs and budget. TCO methodology can be used for vendor selection and sourcing evaluation. [Wouters et al 2005, Degraeve et al, 2000, Degraeve and Roodhooft, 1999,]

Standardised coo. Cost of Ownership, COO, was initially created for the semiconductor industry, wafer process step evaluation, and the methodology has been standardised. The Semiconductor Equipment and Materials International (SEMI) standard (Semi E35, 2001) defines COO as the full cost of embedding, operating and decommissioning; in a factory and laboratory environment, it is the system needed to accommodate a required volume. Thus, in order to determine the $\mathrm{COO}$ of a piece of equipment, the full cost of the equipment and its operation must be divided by the total number of good parts produced over the commissioned lifetime of the equipment. The COO method has also been used for optoelectronics (Ragona 2002), assembly, packaging and inspection in the semiconductor industry (Dance et al 1996). COO is useful also in other technology intensive industries.

As mentioned earlier, engineers and managers need to calculate all of the costs during the lifetime of the equipment. The purchase price of the system is just one indicator of the cost, as presented in the cost pyramid in Figure 4. There are many other costs and 
some of the cost items are difficult to quantify or calculate. All of the parameters shown in Figure 4 are not covered in the SEMI E35 standard.

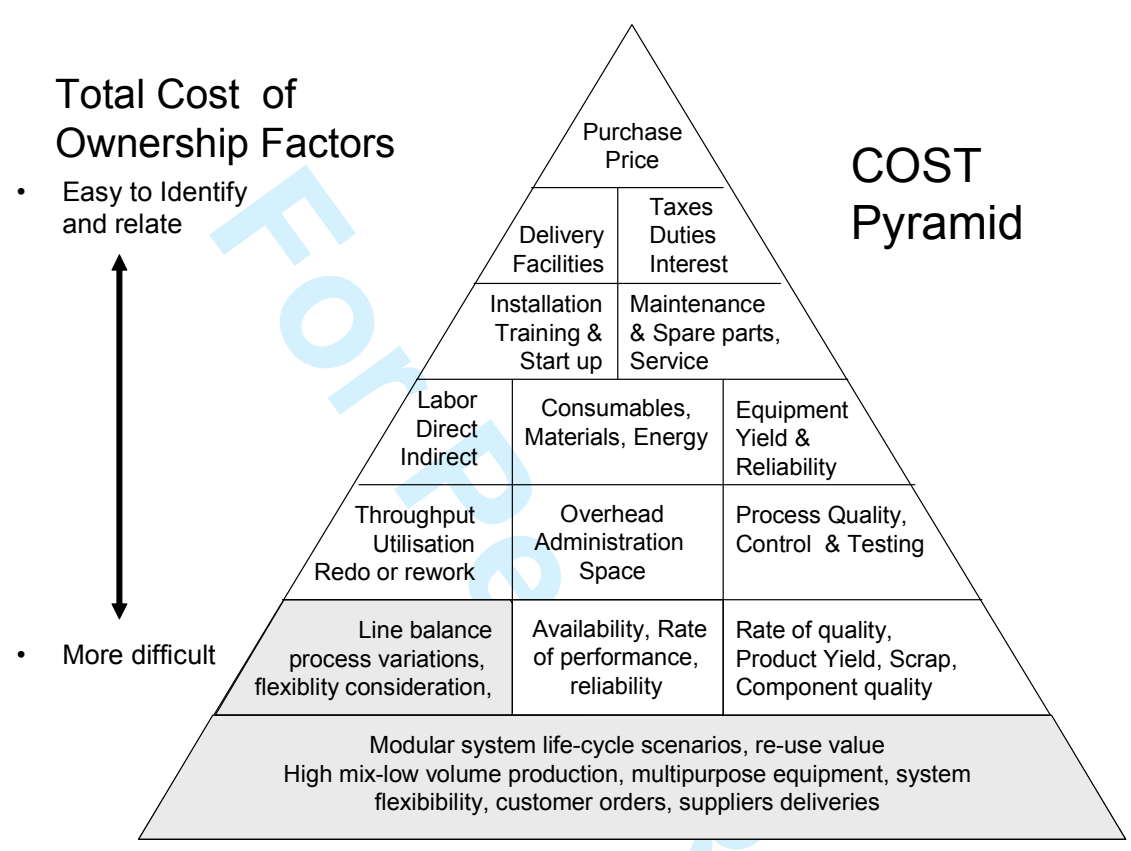

Figure 4: The Cost Pyramid modified from SEMI E35-0701.

\subsection{The E-Race TCO analysis toolkit}

The created tool concept is called the E-Race TCO analysis toolkit, even if analysis does not cover all of the possible costs. The focus is in assembly system design, system concept evaluation and system selection. The development is based on the selected methods shown in Figure 5. The development aims were to measure system performance in terms of overall equipment efficiency, OEE, other technical key performance factors and systems economic value in terms of life cycle and unit costs produced, COO. It could be the factor for winning a contract if the supplier can justify his system design on the basis of life cycle costs, and can include a complete life cycle 
cost analysis in his proposal (i.e., cost breakdown structure, cost profile, etc.). Design engineers also need to estimate the efficiency of the system in terms of the number of good products produced. There are also benefits of using modern assembly system design tools - i.e. modelling, visualisation and 3D simulation - in the design process.

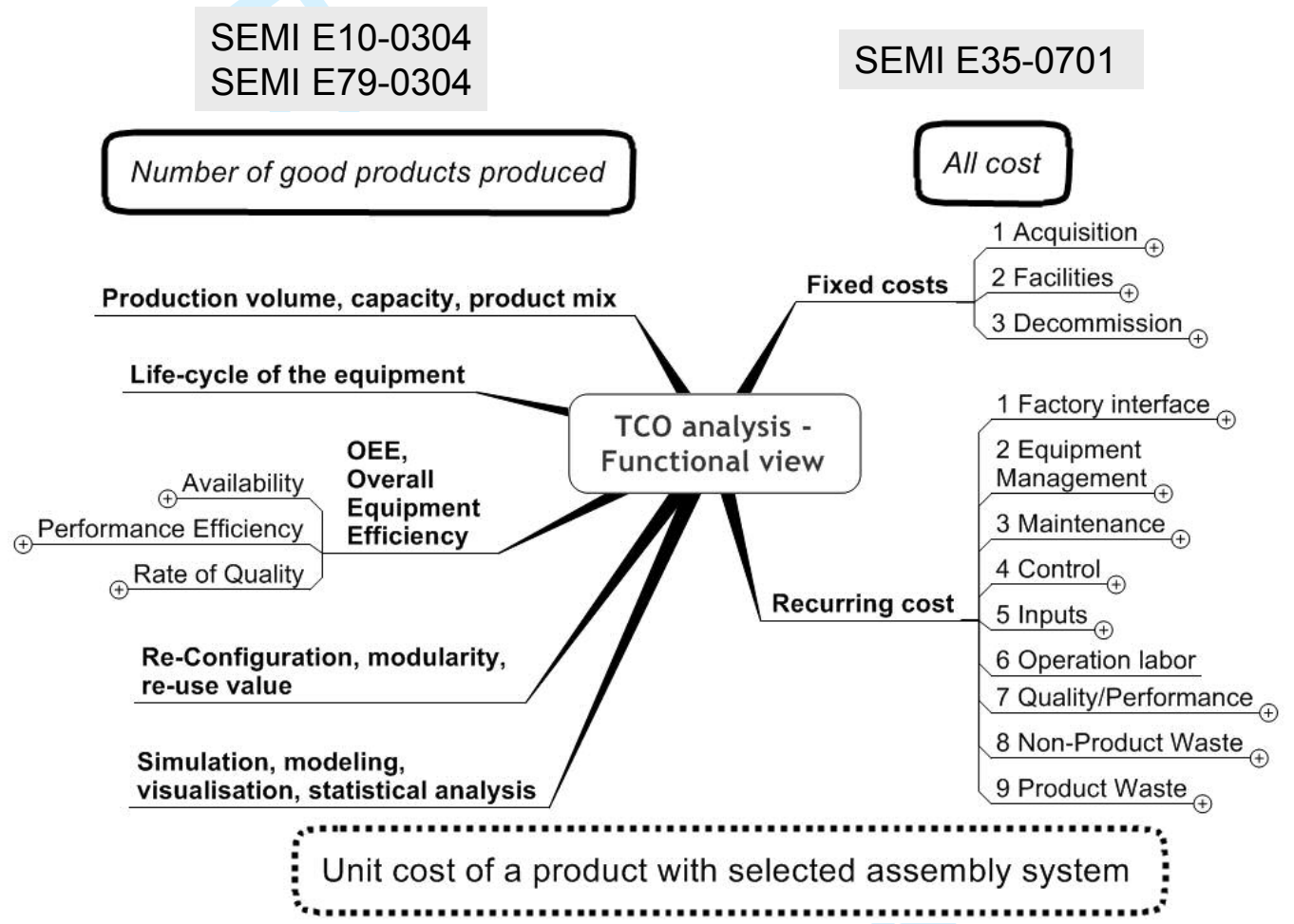

Figure 5. Methodology integration for E-Race TCO analysis toolkit

Overall Equipment Efficiency/Effectiveness, OEE, is used to measure existing equipment availability, efficiency, downtimes and quality rate. The authors are now proposing its use in the final assembly system design evaluation in the electromechanical industry. Simulation analysis and OEE metrics integration has been reported by [Huang, et al 2003] for manufacturing productivity improvement. 
In the following chapters, the selected methods COO and OEE are shown in more detail.

\subsection{Cost of ownership [SEMI E35-0701, Ragona 2002, ]}

The calculated $\mathrm{COO}$ value represents the cost of the process step for each good part produced. It indicates the cost added to that part of the process. The basics of $\mathrm{COO}$ are quite simple and can be summarised as follows:

$$
\mathrm{COO}=\text { Total costs during the system life/Total number of good parts }
$$

The basic formula for COO can be written

$$
\mathrm{COO}=(\mathrm{F} €+\mathrm{L} €+R €+\mathrm{Y} €) /(\mathrm{L} \times \mathrm{T} \times \mathrm{Y} \times \mathrm{U})
$$

\section{Numerator Input Parameters}

(See also Figure 5)

The total cost of owning the equipment consists of the sum of four major parameters

$$
\text { Total cost }=\mathbf{F} €+L €+R €+Y €
$$

Where

$\mathbf{F} €$ represents the initial fixed costs involved in purchasing the equipment: purchase price, cost of installation and initial training, system qualification 
and any movement of the equipment within the factory, and any other costs such as floor space usage, infrastructure needs and decommissioning.

$\mathbf{L} €$ represents the fully burdened labour cost: production personnel, operators needed to run the system. This is usually represented under $\mathrm{R} €$ but in the case of an assembly system, personnel costs should also be known.

$\mathbf{R} €$ represents the sum of all the re-occurring (variation) costs (excluding labour, L€) associated with the equipment over its lifetime; it includes, e.g., the factory interface, equipment management, consumables, maintenance, utilities, floor rent and specialised support personnel. Note: operation labour costs $L €$ could also be included here.

$\mathbf{Y} €$ represents the yield cost associated with the equipment's mishandling of the product. The cost of lost yield due to the equipment is obtained by multiplying the probability of damage by the cost of the product at that stage in the process. Yield costs include costs associated with scrap, including breakage and equipment yield.

The yield cost is obtained by multiplying the number of defective assemblies (N) directly attributable to the workstation by the values of the parts at that stage of assembly $(\mathbf{P} €)$. Thus 


$$
\mathbf{Y}=\mathbf{N} \times \mathbf{P} €
$$

\section{Denominator Input Parameters}

The total number of parts produced by the equipment is dependent on four major variables summarised in the equation below:

Total number of parts produced over the lifetime of the equipment $=\mathbf{L} \times \mathbf{T} \times \mathbf{Y} \times \mathbf{U}$

(4)

Where

L represents the entire lifetime of the equipment (normally 3-5 years for automated equipment)

T represents the throughput rate (parts per year or selected time)

Y represents the composite yield, which includes the cumulative effects of yield loss. The number of good units produced, Y, essentially represents a scaling factor, i.e., a value slightly less than one. Unfortunately, the yield parameter generally has the biggest impact on the $\mathrm{COO}$ value, but it is also the most difficult parameter to determine.

$\mathbf{U}$ represents equipment utilisation, which includes the impact of unscheduled maintenance, the mean time to repair scheduled maintenance, 
assist time, production qualification time and process engineering time. These major factors cause utilisation to be less than $100 \%$.

One way of systematically estimating and classifying equipment efficiency and yield, and also number of good-quality products, is to use OEE methodology as shown in the next chapter.

\subsection{Overall Equipment Efficiency (OEE)}

The authors propose using OEE analysis to calculate or estimate the number of goodquality products, and also to specify work time arrangements. Factory simulations could also be used here, thus analysis methods partially overlap. The major difficulty is to define the input data for the simulation and other analyses.

OEE is the most recent high-level equipment performance metric. It was developed as an equipment effectiveness metric in Japan to measure the effectiveness of a manufacturing technique called Total Productive Maintenance (TPM). It was originally called Overall Equipment Effectiveness. The Semiconductor Equipment and Materials International (SEMI) Metrics Committee changed it to Overall Equipment Efficiency, and the methodology is standardised (SEMI E10-0304, SEMI E79-0304).

The OEE is commonly used for monitoring the running performance of shop floor equipment. OEE is a key performance indicator of how machines, production lines or processes are performing in terms of equipment availability: reliability (MTBF), 
maintainability (MTTR), utilisation, throughput performance or speed and quality produced (yield). It identifies losses due to equipment failure, set-ups and adjustments, idling and minor stops, reduced speed, process defects and start up. Thus, OEE is an allinclusive metric of equipment productivity. All of the above factors are grouped under the following three sub-metrics of equipment efficiency:
1. Availability
2. Performance efficiency
3. Rate of quality

\begin{abstract}
The three sub-metrics and OEE are mathematically related as follows:
OEE, $\%=$ availability $\mathrm{x}$ performance efficiency $\mathrm{x}$ rate of quality $\mathrm{x} 100$
\end{abstract}

General information on OEE can also be obtained from www.oee.com or other Internet sources. There are different opinions on how to calculate OEE and how to translate the acronym - is the last E for Efficiency or Effectiveness? The important factor is to systematically use the same approach all the time, so that it is possible to compare results. The Overall Equipment Efficiency analysis method developed and used by authors is based on SEMI standards. There is a systematic way to classify and study equipment efficiency and time losses (See Figure 6 and Table 1). 


\section{Total Time}

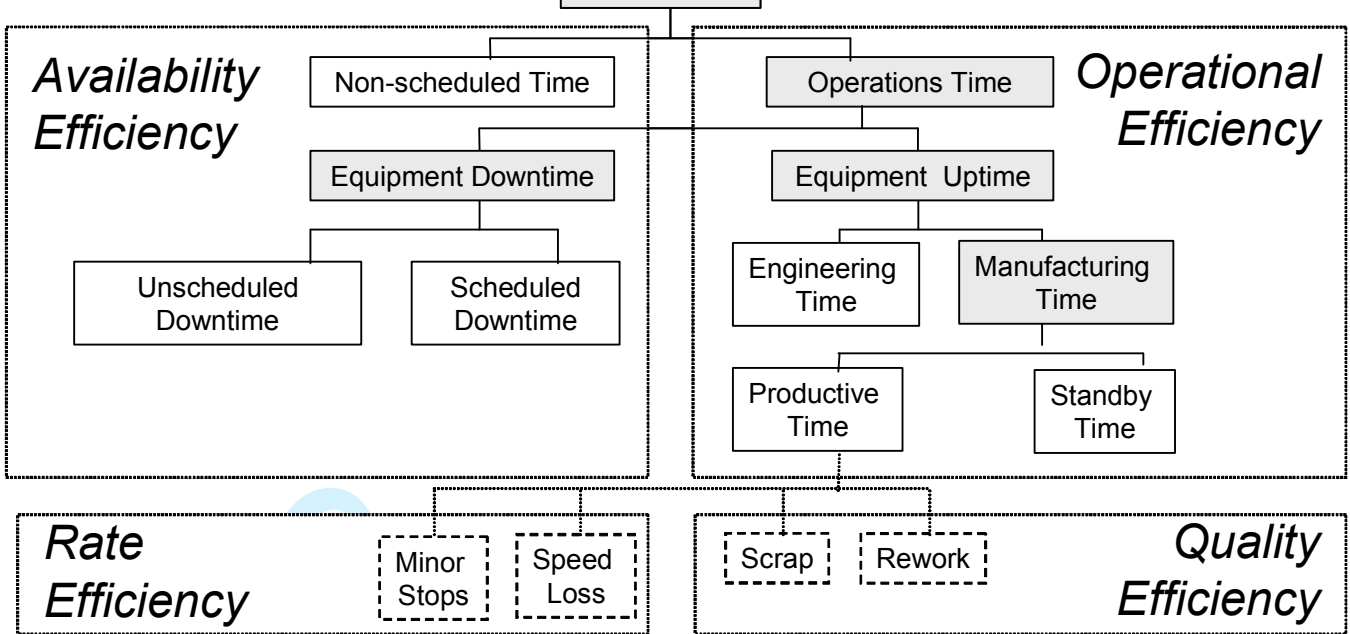

Total Time (365 days $\times 24$ hours)

\begin{tabular}{|c|c|c|}
\hline \multicolumn{2}{|l|}{ Operating time } & \multirow{2}{*}{$\begin{array}{c}\text { Non } \\
\text { Scheduled }\end{array}$} \\
\hline Equipment uptime & Equipment & \\
\hline 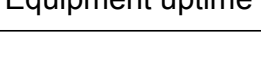 & Downtime & \\
\hline
\end{tabular}

\begin{tabular}{|c|c|c|c|c|c|}
\hline \multicolumn{4}{|c|}{ Manufacturing time } & $\begin{array}{l}\text { Engineering } \\
\text { time }\end{array}$ & Failures \\
\hline \multicolumn{2}{|c|}{ Productive time } & \multicolumn{2}{|c|}{$\begin{array}{l}\text { Standby time } \\
\text { idling/starving }\end{array}$} & \multirow{3}{*}{\multicolumn{2}{|c|}{$\begin{array}{l}\text { OEE and OEE losses } \\
\text { - Setups/adjustments } \\
\text { - Breakdowns } \\
\text { - Idling/minor stoppages } \\
\text { - Reduced speed } \\
\text { - Defects/rework } \\
\text { - Yield }\end{array}$}} \\
\hline \multicolumn{2}{|c|}{ Actual output } & $\begin{array}{l}\begin{array}{l}\text { Reduceo } \\
\text { speed }\end{array} \\
\end{array}$ & $\begin{array}{l}\text { Minor } \\
\text { stoppage }\end{array}$ & & \\
\hline $\begin{array}{l}\text { GOOD } \\
\text { UNITS }\end{array}$ & Rework & Scrap & & & \\
\hline
\end{tabular}

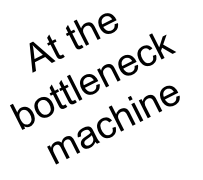

Figure 6: Classification of production time upper level. 
Table 1. OEE Six big losses.

\begin{tabular}{|c|c|c|c|}
\hline $\begin{array}{l}\text { OEE efficiency } \\
\text { calculations }\end{array}$ & Major OEE losses & Losses sub-category & $\begin{array}{l}\text { SEMI E10 efficiency } \\
\text { calculations }\end{array}$ \\
\hline Availability & $\begin{array}{l}\text { Set- } \\
\text { ups/adjustments } \\
\text { Breakdowns }\end{array}$ & $\begin{array}{l}\text { Non-scheduled } \\
\text { Preventative } \\
\text { maintenance } \\
\text { Qualifications } \\
\text { Set-up } \\
\text { Equipment failure } \\
\text { Process failure } \\
\text { Facility failure }\end{array}$ & $\begin{array}{l}\text { Non-scheduled time } \\
\text { Scheduled downtime } \\
\text { Unscheduled downtime }\end{array}$ \\
\hline $\begin{array}{l}\text { Performance } \\
\text { efficiency }\end{array}$ & $\begin{array}{l}\text { Idling/minor } \\
\text { stoppages } \\
\text { Reduced speed }\end{array}$ & $\begin{array}{l}\text { Engineering } \\
\text { No product } \\
\text { No operator } \\
\text { Limited capacity } \\
\text { Slow speed } \\
\text { Stoppage/assist }\end{array}$ & $\begin{array}{l}\text { Engineering time } \\
\text { Standby/idle time } \\
\text { Other time losses } \\
\text { Tool speed losses } \\
\text { Average batch size } \\
\text { Productive }\end{array}$ \\
\hline Rate of quality & $\begin{array}{l}\text { Defects/rework } \\
\text { Yield }\end{array}$ & $\begin{array}{l}\text { Rework } \\
\text { Scrap }\end{array}$ & Quality losses \\
\hline
\end{tabular}

The production engineer should know the production loss factors. This is a way to analyse effective productive time and thus also the number of good units produced. The theoretical optimum cycle time without this kind of analysis overestimates production capacity. This is also a tool for the continuous improvement of a running system.

\section{Methodology developments}

Based on the standardised methodology presented in section 2, the authors have developed E-race TCO, Total Cost of Ownership, analysis Excel workbook. Suitable definitions are used and adapted for electromechanical final assembly system design evaluation. The keywords in analysis are decomposition, cost data and operating time classification. Both the efficiency analysis and cost analysis factors are divided into 
smaller units. Secondly, there is a life cycle aspect as well: cost is divided according to the operational lifetime of the system.

Fixed cost sub-classes are presented in Table 2 and recurring cost sub-classes in Table 3. The cost sub-classes are similar to SEMI E35-0701 standard definitions, but some of the cost classes defined in the standard have not been used.

Table 2. Fixed cost sub-classes, modified from SEMI E35-0701

\begin{tabular}{|c|l|l|l|l|l|}
\hline Functional - Fixed cost & Units & Year 1 & Year 2 & $\ldots$ & Year $\mathrm{n}$ \\
\hline F1.0 Acquisition & $€$ & & & & \\
\hline F1.1 Acquisition: Price & $€$ & & & & \\
\hline F1.2 Acquisition: Purchasing & $€$ & & & & \\
\hline F1.3 Acquisition: Evaluation & $€$ & & & & \\
\hline F1.4 Acquisition: Installation & $€$ & & & & \\
\hline F1.5 Acquisition: Training & days & & & & \\
\hline F1.5.1 Acquisition: Training & $€$ & & & & \\
\hline F2.0 Facilities & $€$ & & & & \\
\hline F2.1 Facilities: Space & $\mathrm{m} 2$ & & & & \\
\hline F2.1.1 Facilities: Space - cost & $€$ & & & & \\
\hline F2.2 Facilities: Infrastructure & $€$ & & & & \\
\hline F2.2.1 Facilities: Infrastructure: Utilities & $€$ & & & & \\
\hline F2.2.2 Facilities: Infrastructure: Services & $€$ & & & & \\
\hline F3.0 Decommissioning & $€$ & & & & \\
\hline F3.1 Decommissioning: Removal & $€$ & & & & \\
\hline F3.2 Decommissioning: Disposal & $€$ & & & & \\
\hline F3.3 Decommissioning: Cleanup & $€$ & & & & \\
\hline
\end{tabular}


Table 3. Recurring cost sub-classes, modified from SEMI E35-0701

\begin{tabular}{|c|c|c|c|c|}
\hline Functional - Recurring cost & units & Year 1 & Year 2 & Year $n$ \\
\hline R1.0 Factory Interface & $€$ & & & \\
\hline R1.1 Factory Interface: Labour & Persons & & & \\
\hline R1.1 Factory Interface: Labour - cost & $€$ & & & \\
\hline R1.2 Factory Interface: Safety & $€$ & & & \\
\hline R1.4 Factory Interface: Infrastructure & $€$ & & & \\
\hline R2.0 Equipment Management & $€$ & & & \\
\hline R2.1 Equipment Management: Supervision & Persons & & & \\
\hline R2.1.1 Equipment Management: Supervision - cost & $€$ & & & \\
\hline R2.2 Equipment Management: Support & Persons & & & \\
\hline R2.2.1 Equipment Management: Support - cost & $€$ & & & \\
\hline R2.3 Equipment Management: Administration & Persons & & & \\
\hline R2.3.1 Equipment Management: Administration - cost & $€$ & & & \\
\hline R3.0 Maintenance & $€$ & & & \\
\hline R3.1 Maintenance: Service Contracts & $€$ & & & \\
\hline R3.2 Maintenance: Labour-Other & Persons & & & \\
\hline R3.2.1 Maintenance: Labour-Other - cost & $€$ & & & \\
\hline R3.3 Maintenance: Spare Parts & $€$ & & & \\
\hline R3.4 Maintenance: Repair Parts & $€$ & & & \\
\hline R4.0 Control & $€$ & & & \\
\hline R4.1 Control: Software & $€$ & & & \\
\hline R4.2 Control: Training & Days*Person & & & \\
\hline R4.2.1 Control: Training - cost & $€$ & & & \\
\hline R4.3 Control: Support & Days*Person & & & \\
\hline R4.3.1 Control: Support - cost & $€$ & & & \\
\hline R4.4 Control: Backup & $€$ & & & \\
\hline R5.0 Inputs & $€$ & & & \\
\hline R5.1 Inputs: Consumables & $€$ & & & \\
\hline R5.2 Inputs: Material & $€ /$ product & & & \\
\hline R5.2 Inputs: Material - cost & $€$ & 7 & & \\
\hline R5.3 Inputs: Utilities & $€$ & & & \\
\hline R6.0 Operation Labour & $€$ & 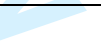 & & \\
\hline R6.0.1 Operation Labour & Persons & & & \\
\hline R9.0 Product Waste & $€$ & & & \\
\hline \multicolumn{5}{|l|}{ R9.3 Scrap: Yield loss } \\
\hline R9.3.1 Scrap: Yield loss - cost & $€$ & & 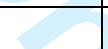 & \\
\hline R9.4 Rework & nbr & & $\overline{3}$ & \\
\hline R9.4.1 Rework - cost & $€$ & & & \\
\hline
\end{tabular}

Similarly, efficiency and production volume is analysed using OEE methodology time elements have been classified, see Figure 6. 


\subsection{E-Race TCO analysis tool prototype}

The development started as an Excel spreadsheet application having separate workbooks for OEE and COO analysis. Simulation was only used as a system configuration and layout visualisation, all data was manually entered into the Excel sheets. Later, both COO and OEE were in the same workbook and the TCO Excel workbook integration to commercial component-based simulation was created.
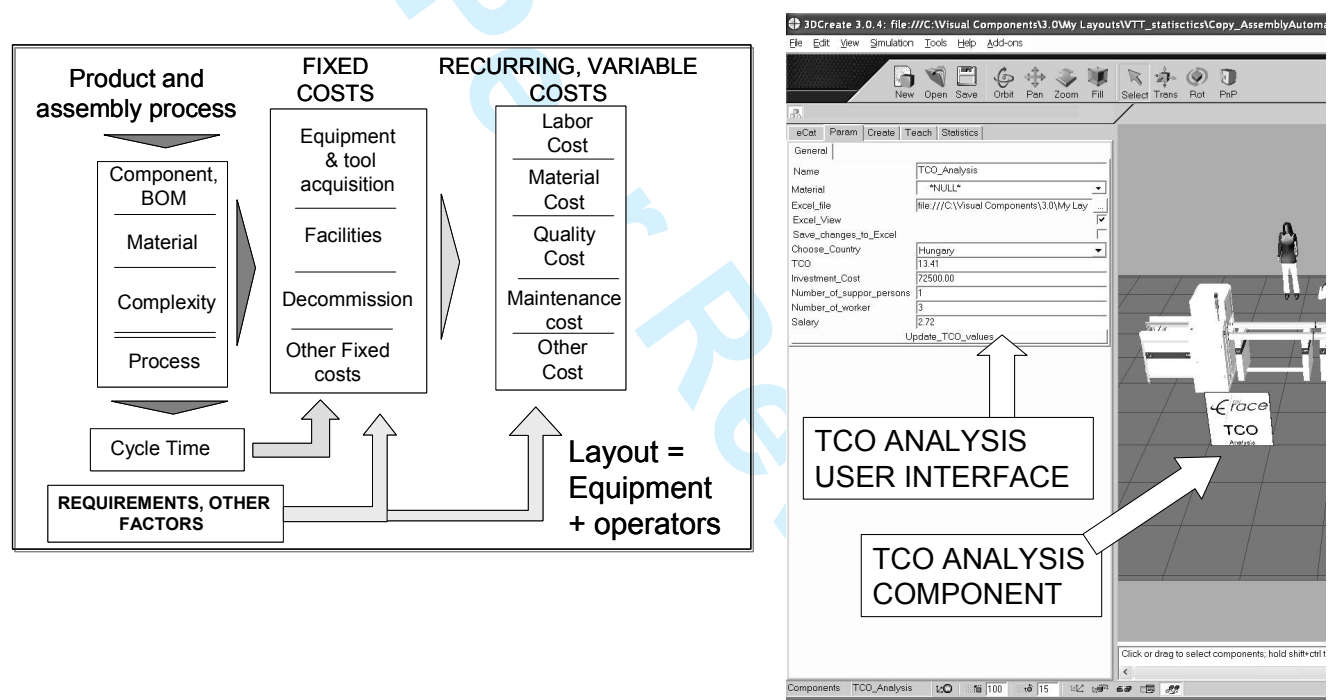

Figure 7. Using the TCO analysis component.

The first TCO analysis component was programmed using the Python language and has an interactive user interface (Figure 7). The layout data from the simulation model was used to provide information about equipment and operator components in the virtual model. Other cost classes must be entered into the Excel sheets manually or the default values must be accepted. The simulation model reads and writes data to the selected cell in the Excel workbook and thus the integration is limited. In the latest existing 
prototype, there is semi-automated interaction between different parts of analysis, i.e., Excel calculations and simulation runs. The advanced version uses a COM interface and Excel-internal links. Each time an engineer selects a component from eCatalogue, a machine or operator, and places it in a simulation model layout, the cost functions start adding equipment and labour cost functions interactively. The actual simulation run results are not automatically used, but can be used as input or for OEE analysis or to verify OEE analysis depending on how the simulation model is built and what kinds of input data are available. An overview of the development is given in Figure 8.

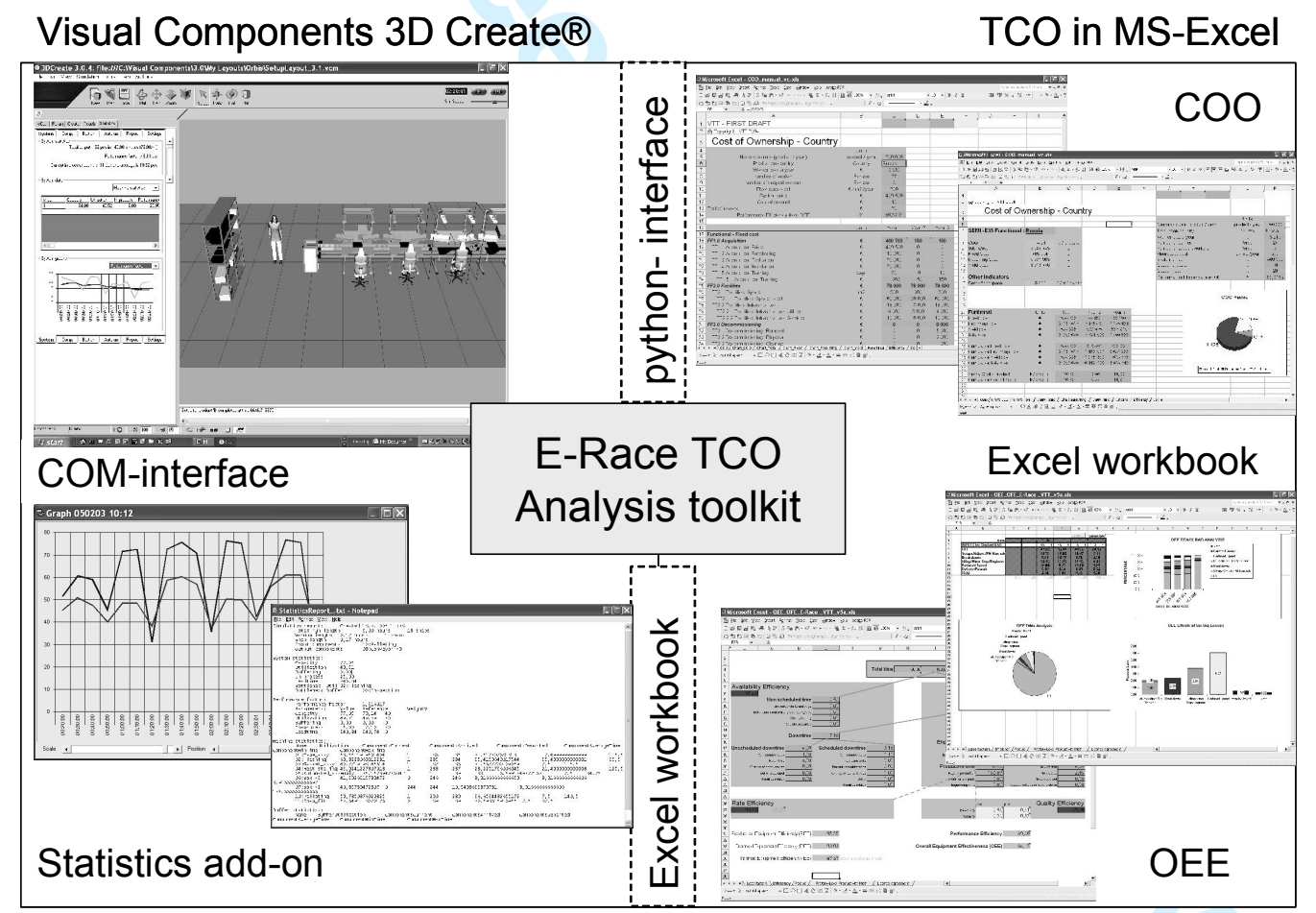

Figure 8. Overview of the TCO analysis toolkit.

In The E-Race TCO Analysis toolkit, the same Excel workbook can be used for analysis with or without simulation software if the engineer inputs all of the necessary data manually. Integration of Total Cost of Ownership (TCO) analysis into the simulation 


\subsection{Analysis flow}

The following shows the interactive nature of the analysis. Using OEE analysis, the engineer can evaluate production volumes from given input values. The theoretical throughputs - i.e., cycle times - need to be known as well as the process descriptions.

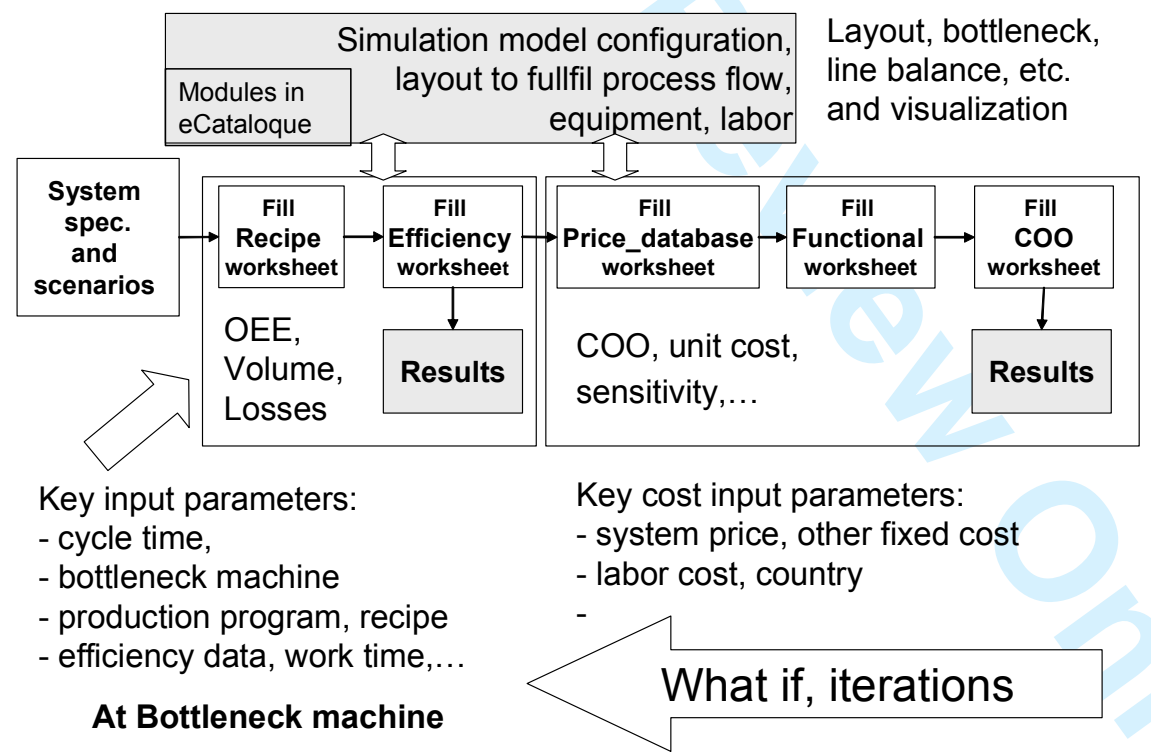

Figure 9. Analysis workflow, iterative steps not shown.

Regarding the volume, one key factor is work time arrangements; adding shifts increases capacity, and increases variable costs. The OEE analysis also shows the major loss factors with given input parameters. 
The next step is to start thinking about the equipment needed to fulfil the process flow and other requirements. In the case of a modular assembly system, the price of the system is defined while selecting suitable "standardised" equipment and designing the system layout to fulfil the required process flow. The labour cost is defined with the equipment selection and degree of automation. Equipment price, need for operators and consumables, and components for the product need to be known for calculating unit costs. All of the other fixed and recurring cost parameters used are shown in Tables 2 and 3. The analysis is iterative and the engineer might need to go back to a previous step until cost, performance and other criteria are fulfilled

The end user and the system supplier could feed the input parameters collaboratively during the sales meeting. The end user has knowledge of the product and processes needed in the assembly and the system supplier has knowledge of the equipment. An assembly system can be evaluated and thus data created for comparison and trade-off analysis.

The following section illustrates the use of TCO analysis.

\section{Case analysis}

The fictitious case study shows the use of the E-Race TCO analysis in assembly line design. The initial data was as follows: needed production volume about 200,000 units per year and the estimated lifetime of the product, and the assembly line, was 3 years. 
The workflow was serial, with 10 work phases and 13 components. The cost of the components for the product was about $10 €$, and the rework cost at the production line was about $20 €$.

The takt times of the system were based on time studies and estimations of bottleneck equipment are not shown here. The takt time for the automated line was about 24 seconds and for the semi-automated line about 72 seconds. There are two different basic semi-automated solutions: three identical assembly lines in one shift, or one semiautomated assembly line in three shifts. The purchase cost of one assembly line is $136,500 €$ and each assembly line needs 9 operators and 2 support persons. There are two options for production countries, in a Western Europe country or an Eastern lowlabour-cost country. The automated system purchase price is $643,000 €$ with 2 operators and 1 support person. The automated line worked in one shift.

There were four basic solutions, scenarios for the assembly system:

- Eastern Semi-automated system, three identical lines in one shift (ES L1S1)

- Eastern Semi-automated system, one line in three shifts (ES L1S3).

- Western Semi-automated system, one line in three shifts (WS LIS3)

- Western Automated line, one line in one shift (WA L1S1). .

Many of potential parameters available in the TCO analysis were constant, since the idea was to make a quick analysis of the alternatives - manual or automated assembly tasks - and also to study the effects of manufacturing in a low-labour-cost country. The comparison was between Russia and Sweden. 


\subsection{OEE and volume analysis}

The first step was to study OEE Loss factors and, naturally, calculate the volume. The results and parameters are shown in Table 4.

Table 4. Table OEE, Volume and Loss Factors

\begin{tabular}{|l|r|r|}
\hline Parameters & 1 shift, S1 & 3 shifts, S3 \\
\hline workdays/week & 5 & 5 \\
\hline shifts/day & 1 & 3 \\
\hline shift length [hr] & 7.5 & 7.5 \\
\hline Calculated volume, products/year & 213785 & 235164 \\
\hline Overall Equipment Effectiveness (OEE), \% & 15.59 & 51.45 \\
\hline Performance Efficiency in OEE, \% & 89.04 & 91.26 \\
\hline Quality Efficiency in OEE, \% & 89.44 & 90.31 \\
\hline Availability Efficiency in OEE, \% & 19.58 & 62.43 \\
\hline Big losses & & 34.89 \\
\hline Set-ups/Adjust./PM Non-scheduled. & 79.53 & 2.68 \\
\hline Breakdowns & 0.89 & 2.98 \\
\hline Idling/Minor Stop/Engineer & 1.39 & 2.48 \\
\hline Reduced Speed & 0.76 & 4.56 \\
\hline Defects/Rework & 1.52 & 0.96 \\
\hline Yield & 0.32 & \\
\hline
\end{tabular}

There were only these two OEE settings in the scenarios. The effects of these parameters on the unit's cost can also be studied. The OEE also shows the potential for capacity flexibility. The major OEE losses are shown there to focus on increasing productivity. Deeper analysis of the efficiency factors depends on the system concept, operator's skill and so on and could be studied. Figure 10 shows the OEE sheet of the TCO calculation, which was used to calculate the parameters for Table 4. 


\subsection{Semi-Automated Assembly Lines}

The main assembly tasks are manual, but material flow and testing is automated (Figure 11). As a starting parameter, a single-shift over 5 days a week was estimated thus having three identical lines to reach the required volume. Optionally, a scenario with one line having three shifts was also analysed (see Table 4 for OEE values).

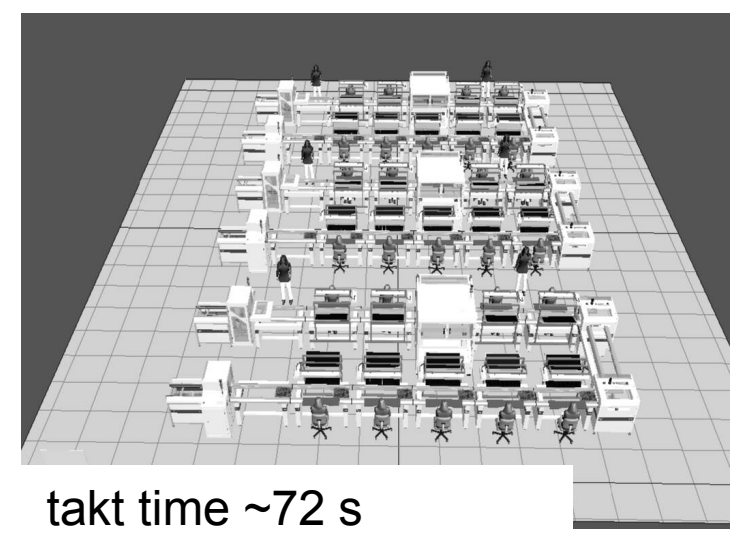


Figure 11: Semi-automated assembly lines.

As an example, only the upper level results are presented here. The parameters are divided into sub-classes and life cycle in years, as shown in the previous section. Using the model, managers and engineers can see whether the system price forms a large fraction of the fixed price (see the following Tables).

Table 5. Semi-automated lines input values for $\mathrm{COO}$

\begin{tabular}{|l|l|r|r|}
\hline Major input & Unit & Scenario ES L3S1 & Scenario ES L1S32 \\
\hline $\begin{array}{l}\text { Calculated volume (product / } \\
\text { year) }\end{array}$ & $\begin{array}{l}\text { product / } \\
\text { year }\end{array}$ & 213785 & 235164 \\
\hline Production country & Country & Russia & Russia \\
\hline Worker cost per year & $€$ & 3910 & 3910 \\
\hline Number of workers & Person & 27 & $9 \times 3$ \\
\hline Number of support workers & Person & 6 & $2 \times 3$ \\
\hline System price & $€$ & 409500 & 136500 \\
\hline
\end{tabular}

OEE data can be found in Table 4. The unit cost, COO for scenario ES L3S1, is 12.47

$€ /$ product. To minimise investment, just purchase one assembly line and operate it in three shifts. Then the unit cost, COO for scenario ES L1S3, is $11.50 €$ /product. The following Tables show the scenario results, yearly and cumulative costs.

Table 6. Summary results for scenario ES L3S1, three lines in one shift.

\begin{tabular}{|l|l|r|r|r|}
\hline Funtional & Units & Year 1 & Year 2 & Year 3 \\
\hline Fixed Cost & $€$ & 544119 & 71,209 & 71209 \\
\hline Recurring Cost & $€$ & 2414690 & 2414284 & 2414284 \\
\hline Yield cost & $€$ & 22947 & 22947 & 22947 \\
\hline Total Cost & $€$ & 2981756 & 2508440 & 2508440 \\
\hline Cumulative Fixed Cost & $€$ & 544119 & 615328 & 686537 \\
\hline Cumulative Recurring Cost & $€$ & 2414690 & 4828974 & 7243258 \\
\hline Cumulative Yield cost & $€$ & 22947 & 45894 & 68841 \\
\hline Cumulative Total Cost & $€$ & 2981756 & 5490196 & 7998636 \\
\hline Yearly Cost / Product & $€ /$ product & 13.947 & 11.733 & 11.733 \\
\hline Cumulative Cost / Product & $€ /$ product & 13.947 & 12.840 & 12.471 \\
\hline
\end{tabular}


Table 7. Summary results for scenario ES L1S3, one line in three shifts.

\begin{tabular}{|l|l|r|r|r|}
\hline Functional & Units & Year 1 & Year 2 & Year 3 \\
\hline Fixed Cost & $€$ & 209694 & 50734 & 50734 \\
\hline Recurring Cost & $€$ & 2576820 & 2576414 & 2576414 \\
\hline Yield cost & $€$ & 23136 & 23136 & 23136 \\
\hline Total Cost & $€$ & 2809649 & 2650283 & 2650283 \\
\hline Cumulative Fixed Cost & $€$ & 209694 & 260428 & 311162 \\
\hline Cumulative Recurring Cost & $€$ & 2576820 & 5153233 & 7729647 \\
\hline Cumulative Yield cost & $€$ & 23136 & 46271 & 69407 \\
\hline Cumulative Total Cost & $€$ & 2809649 & 5459933 & 8110216 \\
\hline Yearly Cost / Product & $€ /$ product & 11.948 & 11.270 & 11.270 \\
\hline Cumulative Cost / Product & $€ /$ product & 11.948 & 11.609 & 11.496 \\
\hline
\end{tabular}

Similarly, scenario WS L1S3, one line in three shifts in a Western country was calculated, the unit cost, $\mathrm{COO}$ is $18.77 € /$ product. For a full comparison, see Table 8

\subsection{Automated Assembly Line}

The automated assembly line (Figure 12) was similarly analysed; the data tables are not shown here. As a starting parameter, operation in a single shift over 5 days a week is used and the production country is Sweden.

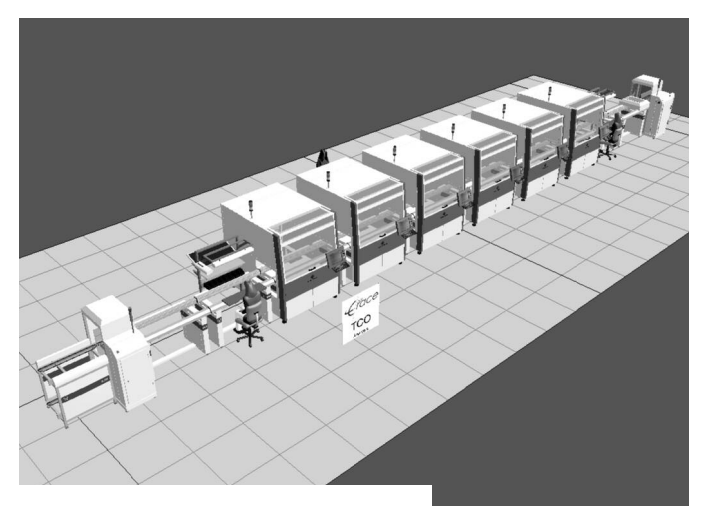

takt time $\sim 24 \mathrm{~s}$

Figure 12: Automated assembly line. 
$\mathrm{COO}$ is $14.31 € /$ product. OEE values are in Table 4. A full comparison can be found in Table 8-

\subsection{Comparison of case scenarios results}

The idea is to first compare the assembly system alternatives with the same system parameters, and later to perform a more accurate analysis. In the concept evaluation, the engineers might not have very accurate data available. Table 8 shows the first-round analysis results; the same efficiency and quality levels were used. In Table 8, Evaluation of concept scenarios, the country is identified with $\mathrm{W}$ or E; S means manual assembly tasks, A automated assembly tasks, L indicates the number of lines, S1 or S3 indicates the number of shifts. The material flow was automated in all cases, as shown in Figures 11 and 12.

Table 8. Evaluation of concept scenarios

\begin{tabular}{|c|c|c|c|c|}
\hline Results & $\begin{array}{l}\text { Russia ES } \\
\text { L1S3 }\end{array}$ & $\begin{array}{l}\text { Sweden WA } \\
\text { L1S3 }\end{array}$ & $\begin{array}{l}\text { Sweden WS } \\
\text { L1S3 }\end{array}$ & $\begin{array}{l}\text { Russia ES } \\
\text { L3S1 }\end{array}$ \\
\hline $\mathrm{COO}, € /$ product & 11.50 & 18.77 & 14.31 & 12.47 \\
\hline Total Cost $[€]$ & 8110216 & 13239864 & 9177761 & 7998636 \\
\hline Fixed Cost $[€]$ & 311162 & 350783 & 1008043 & 686537 \\
\hline Recurring Cost $[€]$ & 7729647 & 12819674 & 8100877 & 7243258 \\
\hline Yield cost $[€]$ & 69407 & 69407 & 68841 & 68841 \\
\hline $\begin{array}{l}\text { Overall Equipment } \\
\text { Effectiveness (OEE), \% }\end{array}$ & 51.45 & 51.45 & 15.59 & 15.59 \\
\hline $\begin{array}{l}\text { Performance Efficiency from } \\
\text { OEE, } \%\end{array}$ & 91.26 & 91.26 & 89.04 & 89.04 \\
\hline $\begin{array}{l}\text { Quality Efficiency from OEE, } \\
\%\end{array}$ & 90.31 & 90.31 & 89.44 & 89.44 \\
\hline $\begin{array}{l}\text { Availability Efficiency from } \\
\text { OEE, \% }\end{array}$ & 62.43 & 62.43 & 19.58 & 19.58 \\
\hline $\begin{array}{l}\text { Calculated volume (product / } \\
\text { year) }\end{array}$ & 235164 & 235164 & 213785 & 213785 \\
\hline Parameters & & & & \\
\hline
\end{tabular}




\begin{tabular}{|c|c|c|c|c|}
\hline Production country & Russia & Sweden & Sweden & Russia \\
\hline Worker cost per year [€] & 3910 & 48505 & 48505 & 3910 \\
\hline Number of workers & 27 & 27 & 2 & 27 \\
\hline Number of support workers & 6 & 6 & 1 & 6 \\
\hline System price $[€]$ & 136500 & 136500 & 643000 & 409500 \\
\hline Cost of product $[€]$ & 10.19 & 10.19 & 10.20 & 10.20 \\
\hline Cost of rework [€] & 20.37 & 20.37 & 20.41 & 20.41 \\
\hline workdays/week & 5 & 5 & 5 & 5 \\
\hline shifts/day & 3 & 3 & 1 & 8 \\
\hline shift length [hr] & 7.5 & 7.5 & 7.5 & 7.5 \\
\hline
\end{tabular}

To summarise, in case the production remains in a western country like Sweden, then automate; in a low-labour-cost country, try running one line in three shifts. In the case of having only one assembly line, there are limitations on capacity flexibility. If managers do estimate that future capacity can be more than one line can produce while working 24 hours a day, 7 days a week, they should also study scenarios with more than one assembly line.

In the second stage of the analysis, the engineers should go deeper into the parameters and perform a what-if analysis, if reasonably accurate data is available. At least the effects of yield, quality and cost should be analysed. Risk analysis can be carried out by maximising or minimising values, thus finding the minimum and maximum for COO. One of the biggest challenges is get the right data. Engineers are able to build very efficient assembly lines, but what if there are no orders?

\subsection{Discussion}

Prototypes of the tools already exist, as shown here; deeper integration is in progress, as well as case studies with real industrial data. The methodology is scaleable, from a 
single machine to factory level. The results are naturally more accurate at the workstation level. In the case of analysing an assembly line, the current TCO model uses throughput data from the bottleneck machine and also yield data from the line as just one figure. For a more precise analysis, engineers need to have all data at single machine level and combine data at line level; currently this can be done by creating a model for each machine and the user manually collating the data at assembly line level. Automating this enhancement will be studied in a new research project.

Even if the development is called Total Cost of Ownership, it is very difficult get data for all of the cost factors. The focus is in system design and the cost of operating it. Some overhead-type costs are not calculated directly, for example, upper level management costs.

The COO standard used in the development has been updated - the latest release is 2005 - but the authors used the 2001 release. There is a similar commercial tool available, dedicated to the semiconductor industry, originally developed together with The Semiconductor Equipment and Materials International (SEMI). More information is available at www.wwk.com. Some cost analysis can be carried out as part of the DFA (Design for Assembly) analysis; the DFA cost analysis does not calculate yield cost.

The novelty of the development presented here is in the integration of different methods. The development aim was to build an analysis system to be used by the system sales engineer for testing different alternatives during the sales meeting with customers. A modular assembly system can easily be configured and system layout 


\section{Conclusions}

Selecting the most appropriate assembly system can offer enormous benefits in terms of product quality, cost reduction and manufacturing productivity. However, selecting the right system for a product depends on a large number of factors and is not a simple problem. This paper proposes a systematic approach to support decision-making in this area and presents a methodology for selecting assembly systems for a product based on technological, efficiency and economic considerations. This paper also presents a case study in the design of a modular reconfigurable final assembly system using simulation, and system life cycle and cost analysis methodology. The theory behind the analysis is also briefly explained.

The basic equation presented here for calculating the $\mathrm{COO}$ was originally developed for wafer fabrication tools and has become a common term among equipment suppliers and equipment users in the semiconductor industry; COO methodology is not well known in the arena of electromechanical assembly. 
Cost of ownership provides an objective analysis method for evaluating decisions. COO can be an implementation of Activity-Based Costing (ABC) that helps in understanding all costs associated with a decision. It improves decisions by relating the costs to the products, processes and services that drive the cost. COO provides an estimate of the life cycle cost. Without such a linkage, it is difficult for organisations to understand the full impact of their decisions on their operating cost structure. With this linkage, COO provides a consistent data-driven method for arriving at important strategic and operational decisions. The analysis highlights details that might be overlooked, thus reducing decision risk.

Finally, COO allows communication between suppliers and users. They are able to speak the same language, comparing similar data and costs using the same analysis methods. Both suppliers and manufacturers can work from verifiable data to support a purchase or implementation plan. The lifetime cost of ownership per manufactured unit is generally sensitive to production throughput rates, overall reliability and yield. In many cases, it is relatively insensitive to the initial purchase price; this can be pinpointed with proper use of analysis. Using the correct parameters, an engineer can justify investments in flexibility and automated equipment, or at least determine threshold values.

OEE is usually a measurement of single machine performance. In the example presented, the calculations are used for a bottleneck machine and, in practice, the Overall Throughput Efficiency of the assembly line is calculated. With a serial line and one product, as used in the example, this can be quite simple. The analysis is more 
complex with mixed production and a layout with parallel operations. Simulation studies can pinpoint bottleneck equipment. One of the limitations of using OEE analysis is that the analysis is process- or equipment-centric and the material flow or work in progress (WIP) is not analysed - another reason for using factory simulations.

Users should remember that, as with all simulation analyses, this kind of simulation is sensitive to the input data, and that input of false information does not produce the right results. The challenge is in getting the correct data. Knowing this, the authors are not aiming at absolute results in the design phase, but, rather, at obtaining data for the comparison of design alternatives. Later, real factory data and accounting data can be used to verify the models and thus improve the results during the next evaluation round and in new system designs.

The authors believe that COO, OEE, modelling and simulation are becoming increasingly important in high-tech decision-making processes. The challenge is to bring system reconfiguration to the analysis automatically; the idea only exists at a conceptual level. Now, reconfiguration and system modularity cost-efficiency analysis requires a lot of manual work.

\section{Further Work}

The developed TCO prototype tools are currently proof of the concept. The development aspects discussed here are the subject of further research currently being undertaken at VTT in a new research project. The cost modelling will be validated with 
real case studies. The focus will be on integration with simulations, factory modelling, material flow and system life cycle scenarios. Other productivity metrics and flexibility issues will also be studied. The aims are to improve integration of the analysis into the component-based simulation software and to obtain analysis data from simulation input data files, and from the results of simulation runs, with minimum effort from the users.

\section{Acknowledgements}

The authors wish to acknowledge the financial support received from the Finnish Funding Agency for Technology and Innovation (TEKES), VTT and Finnish industry. The development is part of the Eureka Factory E!-2851 E-Race project. The national project consortium in Finland, research institutes, technology providers and end users worked together to enhance assembly systems design methodology.

\section{References}

Barringer, H. Paul and David P. Weber, 1996, "Life Cycle Cost Tutorial", Fifth International Conference on Process Plant Reliability October 2-4, 1996,, Gulf Publishing Company, Houston, TX, available from http://www.barringer1.com

Chow, We-Min. Assembly Line Design, Methodology and Applications. Marcel Dekker, Inc., New York and Basel, 1990.

Dance, Daren L., DiFloria, Thomas, and Jimenez, David W. Modeling the Cost of Ownership of Assembly and Inspection. IEEE Transactions On Components, Packaging, And Manufacturing Technology-Part C, Volume. 19, NO. 1, January 1996. Pages 57-60. 
Degraeve, Z., Labro, E. and Roodhooft, F. An evaluation of vendor selection models from a total cost of ownership perspective. European Journal of Operational Research, Volume 125, Issue 1, 16 August 2000, Pages 34-58

Degraeve, Z. and Roodhooft, F., Improving the efficiency of the purchasing process using total cost of ownership information: The case of heating electrodes at Cockerill Sambre S.A. European Journal of Operational Research, Volume 112, Issue 1, 1 January 1999, Pages 42-53

E-Race. http://www.e-race.info/ International project web site. accessed 15 December 2005

Heilala, J.; Helin, K.; Montonen, J.. 2005a. Total cost of ownership analysis for modular final assembly systems. 18th International Conference on Production Research, ICPR 18. Salerno, 31 July - 4 August 2005. University of Salerno

Heilala, J.; Helin, K.; Montonen, J.; Voho, P. and Anttila, M.. 2005b. Integrating cost of ownership analysis into component-based simulation. CARV2005 Today's Reactions Tomorrow's Challenges. 1st Int. Conf. on Changeable, Agile, Reconfigurable and Virtual Production. Münich, 22 - 23 Sept. 2005. Technische Universität München, ss. 385 - 392

Heilala, J., Helin, K., Montonen, J. and Väätäinen, O. Life Cycle And Cost Analysis For Modular Re-Configurable Final Assembly Systems. Third International Precision Assembly Seminar IPAS'2006 Bad Hofgastein, Austria, 19-22 February 2006.

Huang, Samuel H., Dismukes, John P., Shi, J., Su, Qi, Razzak Mousalam A., Bodhale Rohit and Robinson D. Eugene . Manufacturing productivity improvement using effectiveness metrics and simulation analysis. International Journal of Production Research, 2003, Volume. 41, no. 3, 513-527 
Ragona Sid, Cost Of Ownership (COO) For Optoelectronic Manufacturing Equipment. 2002. Microsystems Conference. Rochester, N.Y, 200. available at http://documents.exfo.com/appnotes/anoteBurleigh002-ang.pdf

SEMI E35-0701, 2001, Cost of Ownership for Semiconductor Manufacturing Equipment Metrics, SEMI International Standard, http://www.semi.org.

SEMI E10-0304, 2004, Specification for Definition and Measurement of Equipment Reliability, Availability, and Maintainability (RAM), SEMI International Standard, http://www.semi.org.

SEMI E79-0304, 2004, Specification for Definition and Measurement of Equipment Productivity, SEMI International Standard, http://www.semi.org www.oee.com, accessed 15 December 2005

Visual Components, http://www.visualcomponents.com/portal/company/ accessed 15 December 2005

Wright Williams \& Kelly, http://www.wwk.com/, accessed 15 December 2005

Wouters, Marc, Anderson James C. and Wynstra, Finn. The adoption of total cost of ownership for sourcing decisions-a structural equations analysis. Accounting, Organizations and Society, Volume 30, Issue 2, February 2005, Pages 167-191

Wikipedia (2006). Total cost of ownership.

http://en.wikipedia.org/wiki/Total_cost_of_ownership. accessed 12.4.2006 


\section{List of Figures:}

Figure 1: Component-based simulation is ideal for modular system design

Figure 2: The development aims to improve design quality and communication.

Figure 3: Form requirements to assembly system cost efficiency

Figure 4: The Cost Pyramid modified from SEMI E35-0701.

Figure 5. Methodology integration for E-Race TCO analysis toolkit

Figure 6: Classification of production time upper level.

Figure 7. Using the TCO analysis component.

Figure 8. Overview of the TCO analysis toolkit.

Figure 9. Analysis workflow, iterative steps not shown.

Figure 10. OEE data for 3-shift arrangement.

Figure 11: Semi-automated assembly lines.

Figure 12: Automated assembly line.

\section{List of Tables}

Table 1. OEE Six big losses.

Table 2. Fixed cost sub-classes, modified from SEMI E35-0701

Table 3. Recurring cost sub-classes, modified from SEMI E35-0701

Table 4. Table OEE, Volume and Loss Factors

Table 5. Semi-automated lines input values for $\mathrm{COO}$

Table 6. Summary results for scenario ES L3S1, three lines in one shift.

Table 7. Summary results for scenario ES L1S3, one line in three shifts.

Table 8. Evaluation of concept scenarios 
Figures

Figure 1: Component-based simulation is ideal for modular system design

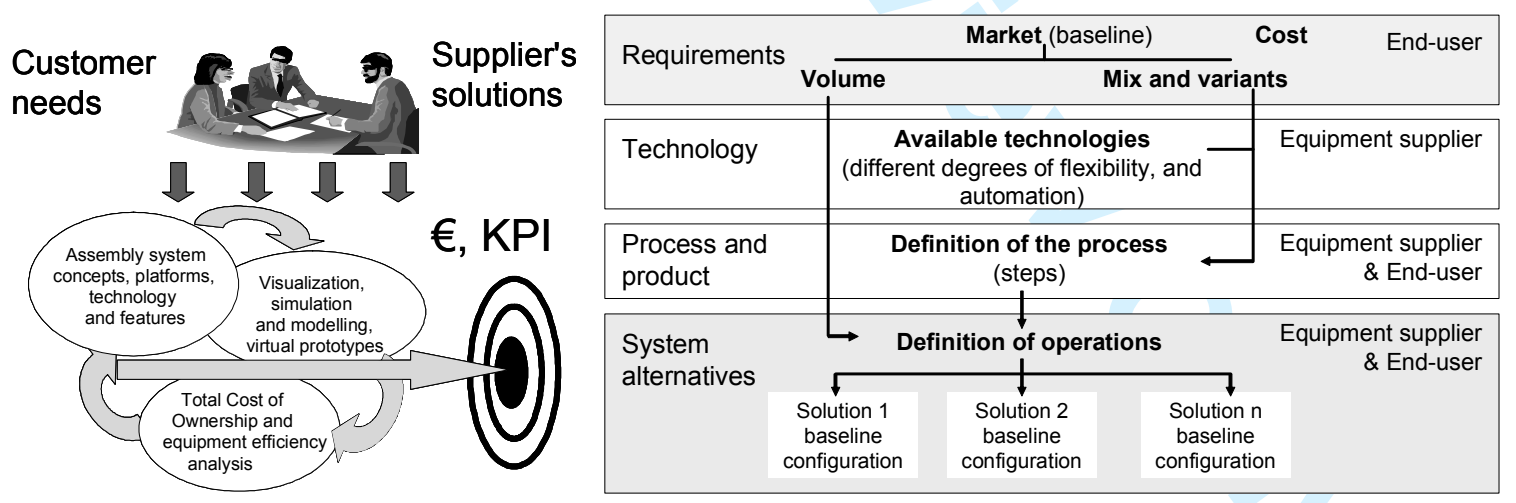

Figure 2: The development aims to improve design quality and communication. 
Figure 3: Form requirements to assembly system cost efficiency

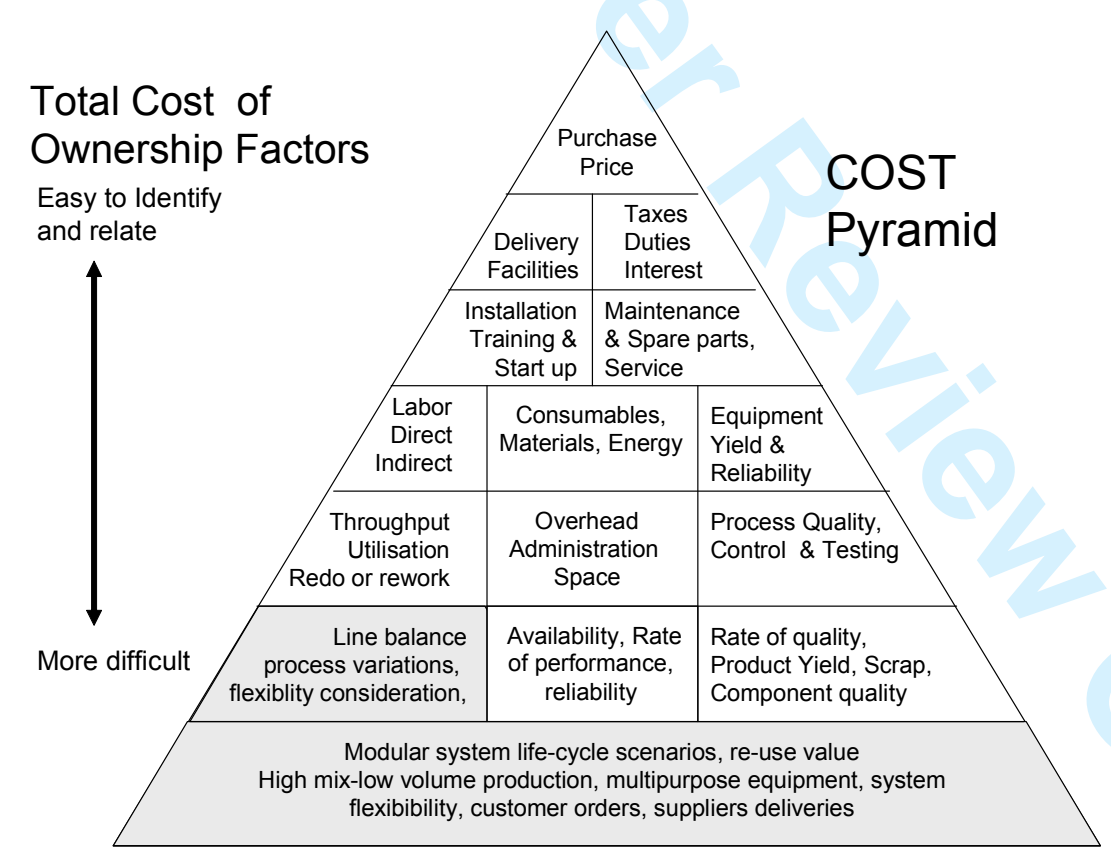

Figure 4: The Cost Pyramid modified from SEMI E35-0701. 


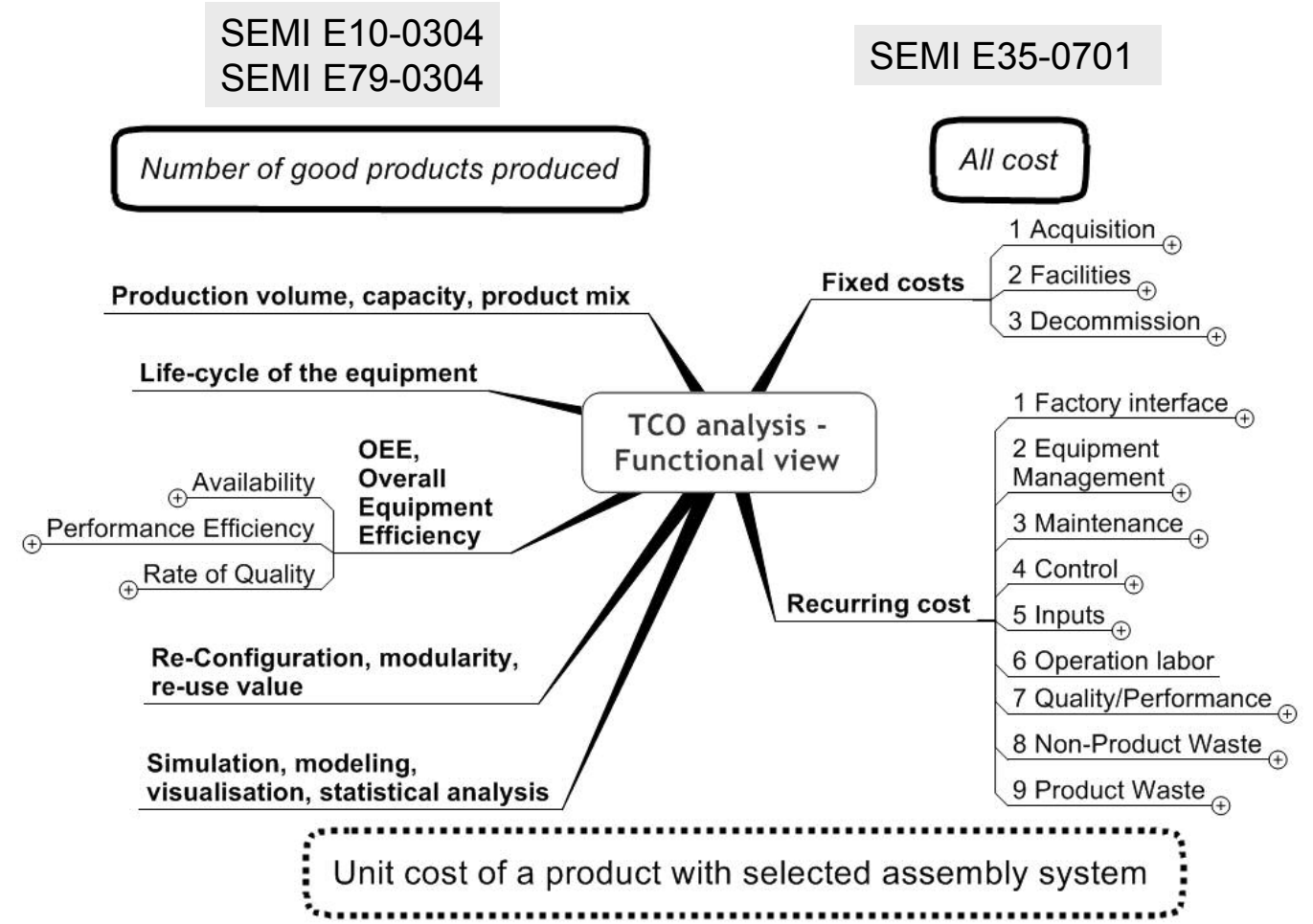

Figure 5. Methodology integration for E-Race TCO analysis toolkit 
Figure 6: Classification of production time upper level. 

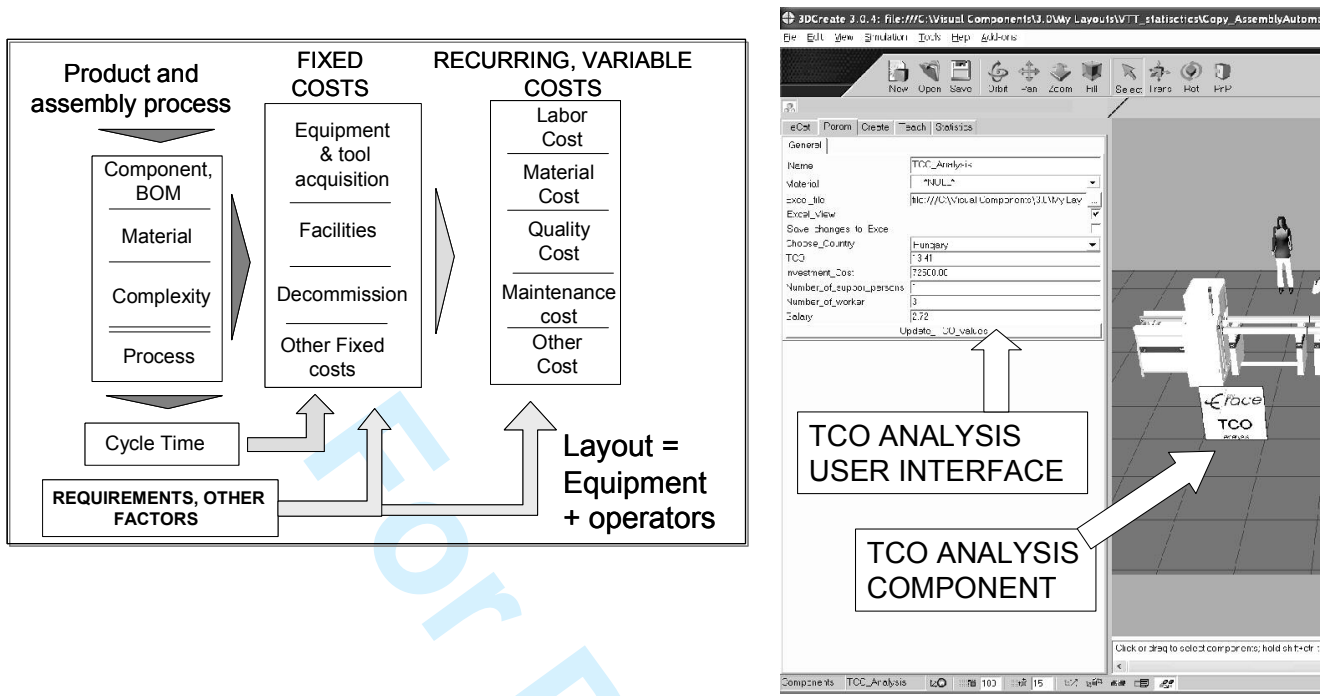

Figure 7. Using the TCO analysis component.

Visual Components 3D Create ${ }^{\circledR}$

TCO in MS-Excel

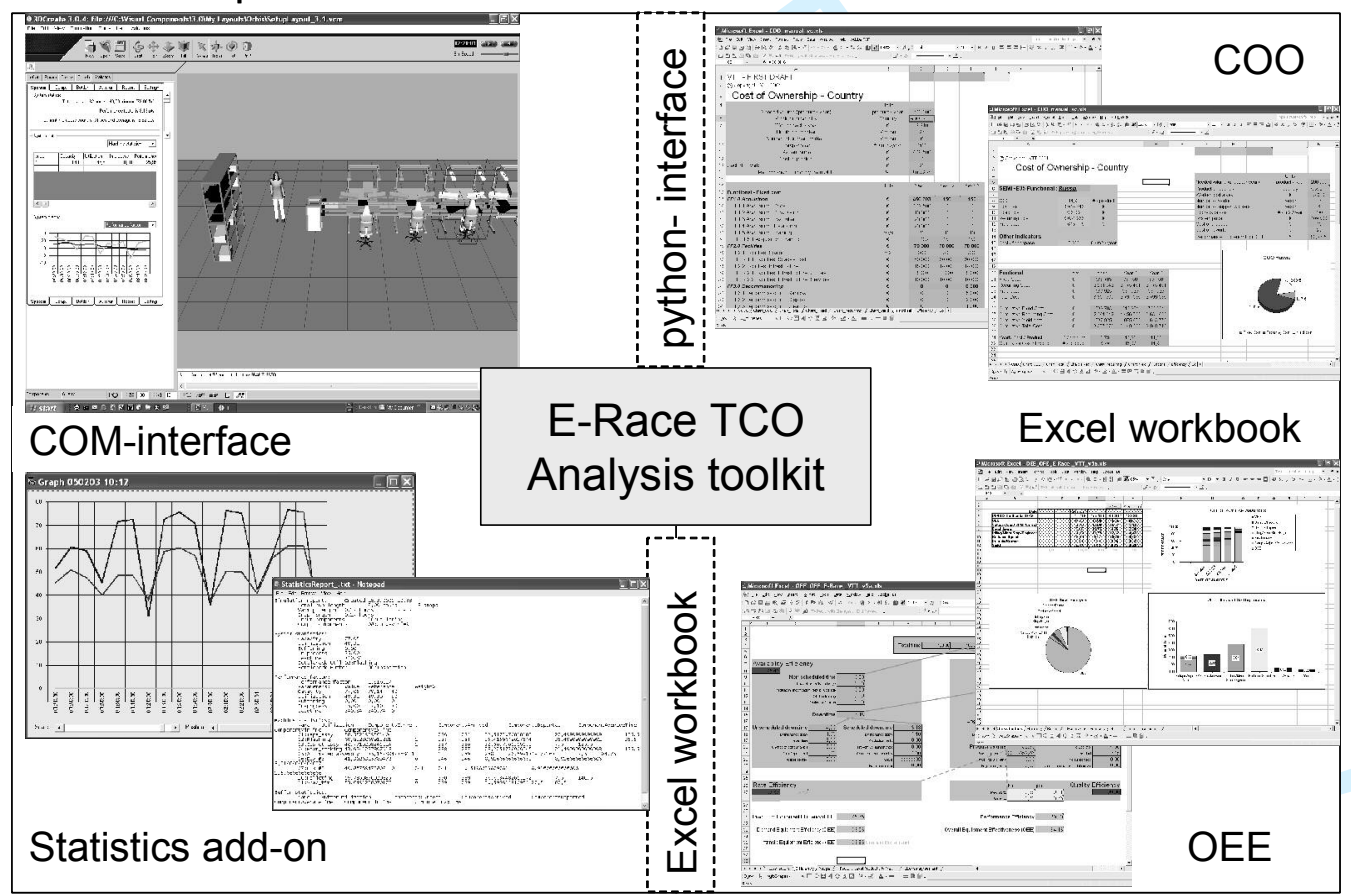

Figure 8. Overview of the TCO analysis toolkit. 


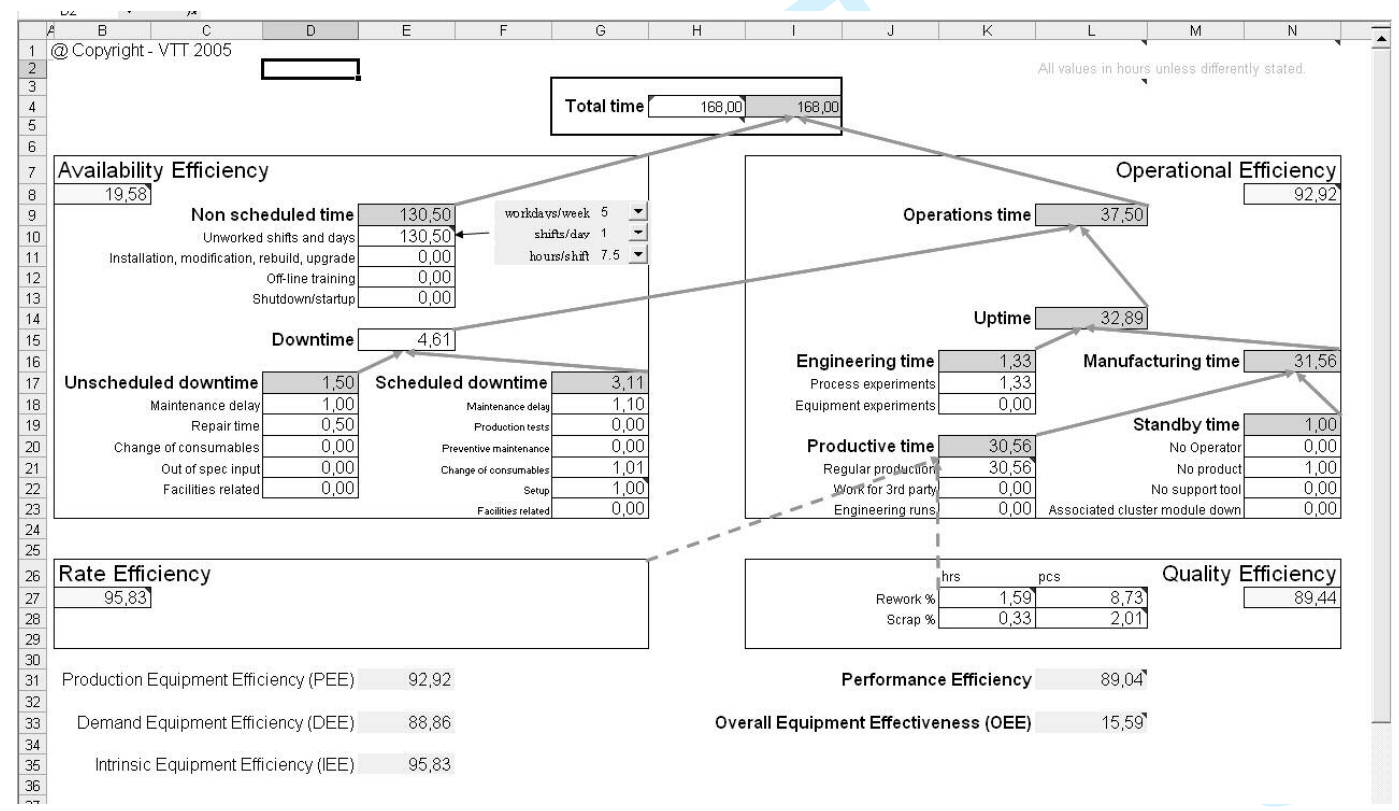

Figure 10. OEE data for 3-shift arrangement. 


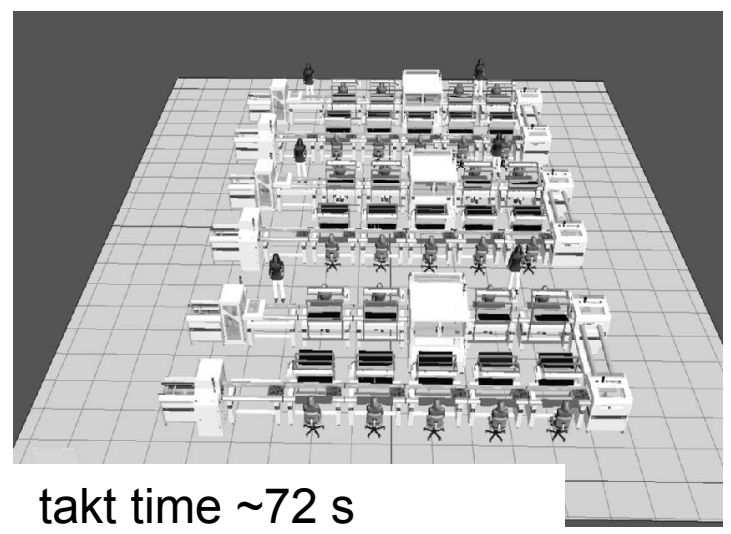

Figure 11: Semi-automated assembly lines.

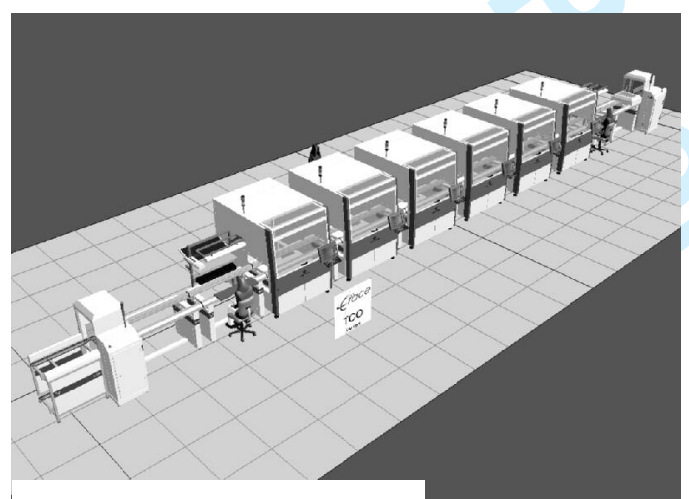

takt time $\sim 24 \mathrm{~s}$

Figure 12: Automated assembly line. 


\section{Tables}

Table 1. OEE Six big losses.

\begin{tabular}{|c|c|c|c|}
\hline $\begin{array}{l}\text { OEE efficiency } \\
\text { calculations }\end{array}$ & Major OEE losses & Losses sub-category & $\begin{array}{l}\text { SEMI E10 efficiency } \\
\text { calculations }\end{array}$ \\
\hline Availability & $\begin{array}{l}\text { Set-ups/adjustments } \\
\text { Breakdowns }\end{array}$ & $\begin{array}{l}\text { Non-scheduled } \\
\text { Preventative } \\
\text { maintenance } \\
\text { Qualifications } \\
\text { Set-up } \\
\text { Equipment failure } \\
\text { Process failure } \\
\text { Facility failure } \\
\end{array}$ & $\begin{array}{l}\text { Non-scheduled time } \\
\text { Scheduled downtime } \\
\text { Unscheduled downtime }\end{array}$ \\
\hline $\begin{array}{l}\text { Performance } \\
\text { efficiency }\end{array}$ & $\begin{array}{l}\text { Idling/minor } \\
\text { stoppages } \\
\text { Reduced speed }\end{array}$ & $\begin{array}{l}\text { Engineering } \\
\text { No product } \\
\text { No operator } \\
\text { Limited capacity } \\
\text { Slow speed } \\
\text { Stoppage/assist }\end{array}$ & $\begin{array}{l}\text { Engineering time } \\
\text { Standby/idle time } \\
\text { Other time losses } \\
\text { Tool speed losses } \\
\text { Average batch size } \\
\text { Productive }\end{array}$ \\
\hline Rate of quality & $\begin{array}{l}\text { Defects/rework } \\
\text { Yield }\end{array}$ & $\begin{array}{l}\text { Rework } \\
\text { Scrap }\end{array}$ & Quality losses \\
\hline
\end{tabular}

Table 2. Fixed cost sub-classes, modified from SEMI E35-0701

\begin{tabular}{|c|l|l|l|l|l|}
\hline Functional - Fixed cost & Units & Year 1 & Year 2 & $\ldots$ & Year $\mathrm{n}$ \\
\hline F1.0 Acquisition & $€$ & & & & \\
\hline F1.1 Acquisition: Price & $€$ & & & & \\
\hline F1.2 Acquisition: Purchasing & $€$ & & & & \\
\hline F1.3 Acquisition: Evaluation & $€$ & & & & \\
\hline F1.4 Acquisition: Installation & $€$ & & & & \\
\hline F1.5 Acquisition: Training & days & & & & \\
\hline F1.5.1 Acquisition: Training & $€$ & & & & \\
\hline F2.0 Facilities & $€$ & & & & \\
\hline F2.1 Facilities: Space & $\mathrm{m} 2$ & & & & \\
\hline F2.1.1 Facilities: Space - cost & $€$ & & & & \\
\hline F2.2 Facilities: Infrastructure & $€$ & & & & \\
\hline F2.2.1 Facilities: Infrastructure: Utilities & $€$ & & & & \\
\hline F2.2.2 Facilities: Infrastructure: Services & $€$ & & & & \\
\hline F3.0 Decommissioning & $€$ & & & & \\
\hline F3.1 Decommissioning: Removal & $€$ & & & & \\
\hline F3.2 Decommissioning: Disposal & $€$ & & & & \\
\hline F3.3 Decommissioning: Cleanup & $€$ & & & & \\
\hline
\end{tabular}


Table 3. Recurring cost sub-classes, modified from SEMI E35-0701

\begin{tabular}{|c|c|c|c|c|}
\hline Functional - Recurring cost & units & Year 1 & Year 2 & Year $n$ \\
\hline R1.0 Factory Interface & $€$ & & & \\
\hline R1.1 Factory Interface: Labour & Persons & & & \\
\hline R1.1 Factory Interface: Labour - cost & $€$ & & & \\
\hline R1.2 Factory Interface: Safety & $€$ & & & \\
\hline R1.4 Factory Interface: Infrastructure & $€$ & & & \\
\hline R2.0 Equipment Management & $€$ & & & \\
\hline R2.1 Equipment Management: Supervision & Persons & & & \\
\hline R2.1.1 Equipment Management: Supervision - cost & $€$ & & & \\
\hline R2.2 Equipment Management: Support & Persons & & & \\
\hline R2.2.1 Equipment Management: Support - cost & $€$ & & & \\
\hline R2.3 Equipment Management: Administration & Persons & & & \\
\hline R2.3.1 Equipment Management: Administration - cost & $€$ & & & \\
\hline R3.0 Maintenance & $€$ & & & \\
\hline R3.1 Maintenance: Service Contracts & $€$ & & & \\
\hline R3.2 Maintenance: Labour-Other & Persons & & & \\
\hline R3.2.1 Maintenance: Labour-Other - cost & $€$ & & & \\
\hline R3.3 Maintenance: Spare Parts & $€$ & & & \\
\hline R3.4 Maintenance: Repair Parts & $€$ & & & \\
\hline R4.0 Control & $€$ & & & \\
\hline R4.1 Control: Software & $€$ & & & \\
\hline R4.2 Control: Training & Days*Person & & & \\
\hline R4.2.1 Control: Training - cost & $€$ & & & \\
\hline R4.3 Control: Support & Days*Person & & & \\
\hline R4.3.1 Control: Support - cost & $€$ & & & \\
\hline R4.4 Control: Backup & $\overline{a n}$ & & & \\
\hline R5.0 Inputs & 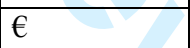 & & & \\
\hline R5.1 Inputs: Consumables & $€$ & 20 & & \\
\hline R5.2 Inputs: Material & $€ /$ product & & & \\
\hline R5.2 Inputs: Material - cost & $€$ & 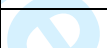 & & \\
\hline R5.3 Inputs: Utilities & $€$ & +2 & & \\
\hline R6.0 Operation Labour & $€$ & & 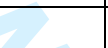 & \\
\hline R6.0.1 Operation Labour & Persons & & & \\
\hline R9.0 Product Waste & $€$ & & & \\
\hline \multicolumn{5}{|l|}{ R9.3 Scrap: Yield loss } \\
\hline R9.3.1 Scrap: Yield loss - cost & $€$ & & & \\
\hline R9.4 Rework & nbr & & & \\
\hline R9.4.1 Rework - cost & $€$ & & & 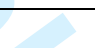 \\
\hline
\end{tabular}


Table 4. Table OEE, Volume and Loss Factors

\begin{tabular}{|l|r|r|}
\hline Parameters & 1 shift, S1 & 3 shifts, S3 \\
\hline workdays/week & 5 & 5 \\
\hline shifts/day & 1 & 3 \\
\hline shift length [hr] & 7.5 & 7.5 \\
\hline Calculated volume, products/year & 213785 & 235164 \\
\hline Overall Equipment Effectiveness (OEE), \% & 15.59 & 51.45 \\
\hline Performance Efficiency in OEE, \% & 89.04 & 91.26 \\
\hline Quality Efficiency in OEE, \% & 89.44 & 90.31 \\
\hline Availability Efficiency in OEE, \% & 19.58 & 62.43 \\
\hline Big losses & & 34.89 \\
\hline Set-ups/Adjust./PM Non-scheduled. & 79.53 & 2.68 \\
\hline Breakdowns & 0.89 & 2.98 \\
\hline Idling/Minor Stop/Engineer & 1.39 & 2.48 \\
\hline Reduced Speed & 0.76 & 4.56 \\
\hline Defects/Rework & 1.52 & 0.96 \\
\hline Yield & 0.32 & \\
\hline
\end{tabular}

Table 5. Semi-automated lines input values for $\mathrm{COO}$

\begin{tabular}{|l|l|r|r|}
\hline Major input & Unit & Scenario ES L3S1 & Scenario ES L1S32 \\
\hline $\begin{array}{l}\text { Calculated volume (product / } \\
\text { year) }\end{array}$ & $\begin{array}{l}\text { product } \\
\text { year }\end{array}$ & 213785 & 235164 \\
\hline Production country & Country & Russia & Russia \\
\hline Worker cost per year & $€$ & 3910 & 3910 \\
\hline Number of workers & Person & 27 & $9 \times 3$ \\
\hline Number of support workers & Person & 6 & $2 \times 3$ \\
\hline System price & $€$ & 409500 & 136500 \\
\hline
\end{tabular}


Table 6. Summary results for scenario ES L3S1, three lines in one shift.

\begin{tabular}{|l|l|r|r|r|}
\hline Funtional & Units & Year 1 & Year 2 & Year 3 \\
\hline Fixed Cost & $€$ & 544119 & 71,209 & 71209 \\
\hline Recurring Cost & $€$ & 2414690 & 2414284 & 2414284 \\
\hline Yield cost & $€$ & 22947 & 22947 & 22947 \\
\hline Total Cost & $€$ & 2981756 & 2508440 & 2508440 \\
\hline Cumulative Fixed Cost & $€$ & 544119 & 615328 & 686537 \\
\hline Cumulative Recurring Cost & $€$ & 2414690 & 4828974 & 7243258 \\
\hline Cumulative Yield cost & $€$ & 22947 & 45894 & 68841 \\
\hline Cumulative Total Cost & $€$ & 2981756 & 5490196 & 7998636 \\
\hline Yearly Cost / Product & $€ /$ product & 13.947 & 11.733 & 11.733 \\
\hline Cumulative Cost / Product & $€ /$ product & 13.947 & 12.840 & 12.471 \\
\hline
\end{tabular}

Table 7. Summary results for scenario ES L1S3, one line in three shifts.

\begin{tabular}{|l|l|r|r|r|}
\hline Functional & Units & Year 1 & Year 2 & Year 3 \\
\hline Fixed Cost & $€$ & 209694 & 50734 & 50734 \\
\hline Recurring Cost & $€$ & 2576820 & 2576414 & 2576414 \\
\hline Yield cost & $€$ & 23136 & 23136 & 23136 \\
\hline Total Cost & $€$ & 2809649 & 2650283 & 2650283 \\
\hline Cumulative Fixed Cost & $€$ & 209694 & 260428 & 311162 \\
\hline Cumulative Recurring Cost & $€$ & 2576820 & 5153233 & 7729647 \\
\hline Cumulative Yield cost & $€$ & 23136 & 46271 & 69407 \\
\hline Cumulative Total Cost & $€$ & 2809649 & 5459933 & 8110216 \\
\hline Yearly Cost / Product & $€ /$ product & 11.948 & 11.270 & 11.270 \\
\hline Cumulative Cost / Product & $€ /$ product & 11.948 & 11.609 & 11.496 \\
\hline
\end{tabular}


Table 8. Evaluation of concept scenarios

\begin{tabular}{|c|c|c|c|c|}
\hline Results & $\begin{array}{l}\text { Russia ES } \\
\text { L1S3 }\end{array}$ & $\begin{array}{l}\text { Sweden WA } \\
\text { L1S3 }\end{array}$ & $\begin{array}{l}\text { Sweden WS } \\
\text { L1S3 }\end{array}$ & $\begin{array}{l}\text { Russia ES } \\
\text { L3S1 }\end{array}$ \\
\hline $\mathrm{COO}, € /$ product & 11.50 & 18.77 & 14.31 & 12.47 \\
\hline Total Cost $[€]$ & 8110216 & 13239864 & 9177761 & 7998636 \\
\hline Fixed Cost $[€]$ & 311162 & 350783 & 1008043 & 686537 \\
\hline Recurring Cost $[€]$ & 7729647 & 12819674 & 8100877 & 7243258 \\
\hline Yield cost $[€]$ & 69407 & 69407 & 68841 & 68841 \\
\hline $\begin{array}{l}\text { Overall Equipment Effectiveness } \\
(\mathrm{OEE}), \%\end{array}$ & 51.45 & 51.45 & 15.59 & 15.59 \\
\hline $\begin{array}{l}\text { Performance Efficiency from OEE, } \\
\%\end{array}$ & 91.26 & 91.26 & 89.04 & 89.04 \\
\hline Quality Efficiency from OEE, \% & 90.31 & 90.31 & 89.44 & 89.44 \\
\hline $\begin{array}{l}\text { Availability Efficiency from OEE, } \\
\%\end{array}$ & 62.43 & 62.43 & 19.58 & 19.58 \\
\hline Calculated volume (product / year) & 235164 & 235164 & 213785 & 213785 \\
\hline \multicolumn{5}{|l|}{ Parameters } \\
\hline Production country & Russia & Sweden & Sweden & Russia \\
\hline Worker cost per year $[€]$ & 3910 & 48505 & 48505 & 3910 \\
\hline Number of workers & +2 & 27 & 2 & 27 \\
\hline Number of support workers & 6 & 6 & 1 & 6 \\
\hline System price $[€]$ & 136500 & 136500 & 643000 & 409500 \\
\hline Cost of product [€] & 10.19 & 10.19 & 10.20 & 10.20 \\
\hline Cost of rework [€] & 20.37 & 20.37 & 20.41 & 20.41 \\
\hline workdays/week & 5 & 5 & 5 & 5 \\
\hline shifts/day & 3 & 2 & 1 & 1 \\
\hline shift length [hr] & 7.5 & 7.5 & 7.5 & 7.5 \\
\hline
\end{tabular}

